\title{
Eruptive history of Arenal Volcano, Costa Rica, 7 ka to present
}

\author{
Gerardo J. Soto *, Guillermo E. Alvarado \\ Área de Amenazas y Auscultación Sísmica y Volcánica, Instituto Costarricense de Electricidad, Apdo 10032-1000, San José, Costa Rica
}

Received 30 June 2005; accepted 28 March 2006

\begin{abstract}
New tephra-stratigraphic studies of Arenal volcano have been used to update its volcanic history. Deposits of major eruptions are renamed AR-1 to AR-22 (from older to younger, in stratigraphic order), extending from 7 ka B.P. to 1968 A.D. Arenal tephras overlie regional tuffs that are $>20,000$ years old. Isopachs and characteristics of the most relevant and recognized fall deposits are presented. Among Arenal eruptions, plinian events like AR-20, AR-15, AR-12 and AR-9, were the most relevant, with tephra volumes up to $0.44 \mathrm{~km}^{3}$. These plinian eruptions are separated by periods of 750-1080 years. Also 8 subplinian, 7 violent strombolian and 2 vulcanian eruptions have been recognized and correlated in Arenal's tephra sequence. Tens of other minor explosive eruptions resembling in size to AR-22, which occurred in July 1968, have been recognized. Lava cycles have generally followed the plinian eruptions. Typical erupting volumes for these cycles have been in the order of $\sim 0.7 \mathrm{~km}^{3}$. The estimated total volume of tephra fall is $\sim 4.5 \mathrm{~km}^{3}$. The rate of total volcanics erupted is $\sim 2.7 \mathrm{~km}^{3} \mathrm{ka}^{-1}\left(0.086 \mathrm{~m}^{3} \mathrm{~s}^{-1}\right)$. The tephra sequence previous to AR-9 (3200 B.P.-7000 B.P.) has no dark soils, whereas the overlying sequence does. It is presumed to be a consequence of regional climatic changes from a dry environment to a rainy tropical one.
\end{abstract}

(C) 2006 Elsevier B.V. All rights reserved.

Keywords: Arenal volcano; eruptive history; tephra stratigraphy; lava fields; eruptive rate

\section{Introduction}

The volcanic arc of Costa Rica is divided in three sections - Guanacaste, Tilarán and Central Ranges - with Arenal volcano at the northwestern end of Tilarán Range (Fig. 1). The whole volcanic front runs from northwest to southeast, $150 \mathrm{~km}$ landward of the Mid American Trench. The crust under Arenal has a thickness around $40 \mathrm{~km}$ (43.5 $\pm 7 \mathrm{~km}$ according to Matumoto et al., 1977; 38$40 \mathrm{~km}$ according to Sallares et al., 1999; and $\sim 40 \mathrm{~km}$

\footnotetext{
* Corresponding author. Present address: Apdo. 360-2350 San Francisco Dos Ríos, Costa Rica. Tel.: +506 2800128.

E-mail address: katomirodriguez@yahoo.com (G.J. Soto).
}

according to Yao et al., 1999), and its lower part includes granulites and metagabbros (Sachs and Alvarado, 1996). The youngest eruptive centers of the Tilarán Range are Los Perdidos Complex (ca. $90 \mathrm{ka}$ ), Chato volcano (38 ka to $3.8 \mathrm{ka}$; Gillot et al., 1994), and Arenal, whose eruptive history is detailed in this paper.

References to Arenal as a volcano date back to the 19th century. It has been called by several different names: Los Ahogados, volcán de Costa Rica, Río Frío, volcán de los Canastos or Pelón, Pan de Azúcar and cerro de los Guatusos. The area where it is located remained poorly explored until 1937, when a documented mission explored the summit (Alvarado, 2000). Nevertheless, Arenal continued to be nearly ignored by local geographic texts until its disastrous eruption in July 1968. 

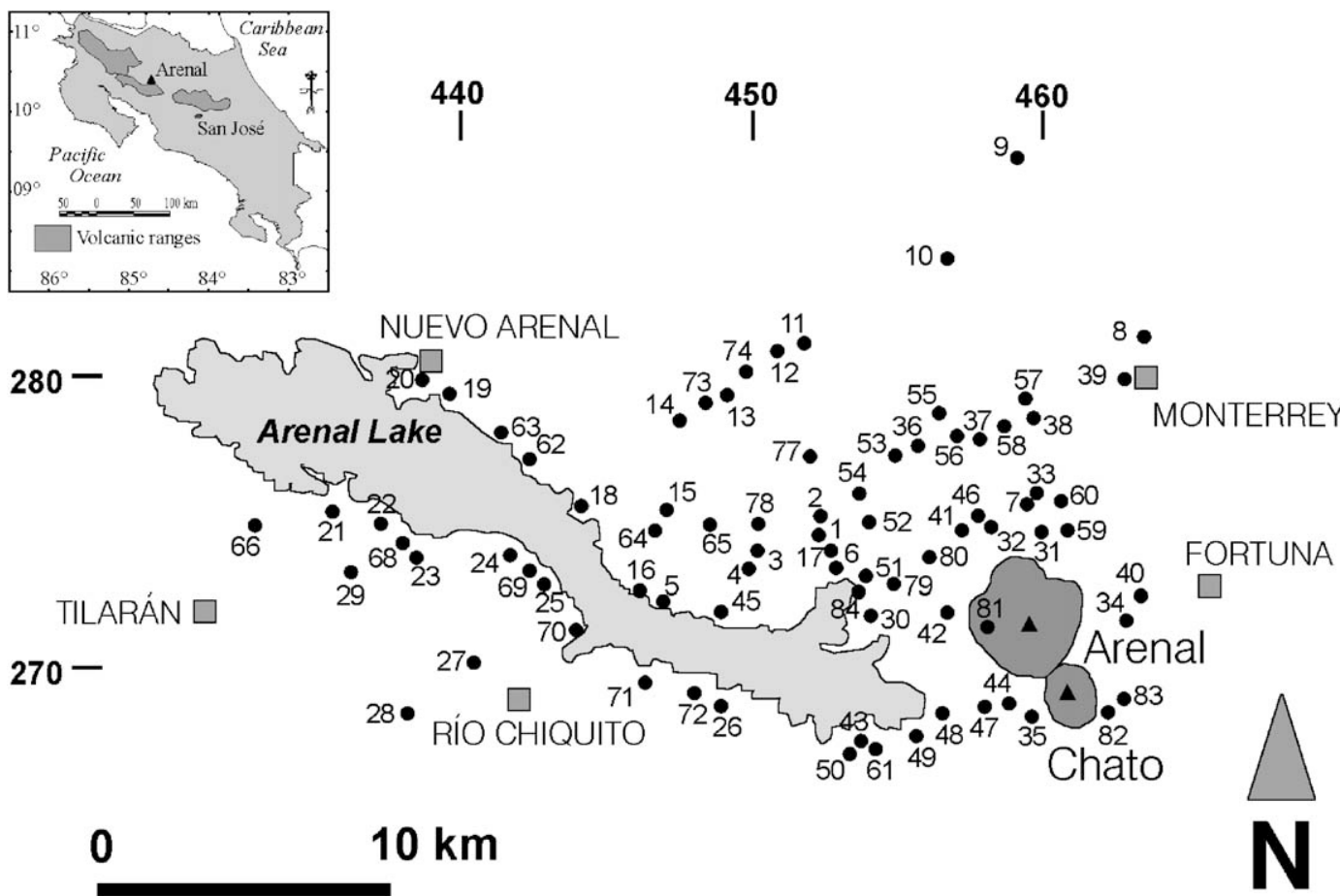

Fig. 1. Location of Arenal volcano and the 84 sections studied (67, 75 and 76 are distal sections out of this area). Coordinates are local Lambert Costa Rica Norte.

\subsection{Previous works and objectives}

The region around Arenal volcano and the reservoir are covered by a complex stratigraphy of Arenal tephra. These tephras overlay Miocene-Pleistocene volcanic and sedimentary rocks of the Venado and Monteverde formations, as well as the Aguacate Group, and Los Perdidos and Chato volcanics. Most of the local basement consists of volcanics from Monteverde and Aguacate, which are topped by a well developed lateritic paleosol (Malavassi and Madrigal, 1970; Tournon and Alvarado, 1995).

Arenal's eruptive history has been reconstructed based on the previous papers by Malavassi (1979), Melson (1982, 1984), Chiesa (1987a,b), Borgia et al. (1988), Ghigliotti et al. $(1992,1993)$ and Soto et al. $(1998,2000)$. Melson $(1982,1984)$ defined a type stratigraphic section revealed in an extensive quarry, which he termed "El Tajo", identifying the units with the prefix ET- $x$, where each unit is topped by a soil horizon (except ET-4). This section, unfortunately, was covered by the waters of the Arenal reservoir in 1978. Borgia et al. (1988) used the same nomenclature, with slight changes in unit definitions of the tephra stratigraphy, lava sequence, new radiocarbon ages, and a geological map. Chiesa (1987a,b) was the first to carry out a survey of tephra sections around Arenal, in order to correlate the deposits previously described by
Melson. These studies also mapped the distribution of the last dacitic eruption deposits, called ET-2. Sheets et al. (1991) wrote about the relationship between prehistory and volcanism in the Arenal area, suggesting that the first major explosive eruption of Arenal dates to about 1800 B.C. (3750 B.P.).

Between 1984 and 1996, a project was undertaken by the Instituto Costarricense de Electricidad (ICE), with the goal of assessing Arenal's volcanic hazards. The results were mainly written as internal and/or local reports in Spanish (Ghigliotti et al., 1992, 1993; Soto et al., 1998, 2000). They revised most of the sections cited by Chiesa (1987a,b), measured 82 new sections (Fig. 1), and established new correlations in a wider area, finding several new units not previously described. This paper compiles and reevaluates these results, together with additional field work (revisited and 2 additional sections) conducted after 1996.

Whereas numerous roads allow the observation of many tephra sections in most directions from Arenal volcano, observations are limited on the southern side of Arenal, toward Chato volcano, by the lack of access roads and dense forest cover. Toward the west, near the lake, explosive deposits reach their greatest thickness. $25 \mathrm{~km}$ WNW from Arenal, the eruptive sequence has $1.2 \mathrm{~m}$ thickness, with 7 or 8 ash layers overlying a 
reddish paleosol. On the distal northern sections, there is only one fall layer overlying the Aguacate Group. On the eastern zone, several layers of reworked materials are mixed with pyroclastic flow, lahar and alluvium deposits from Arenal and Chato volcanoes.

The tephra stratigraphy developed by Ghigliotti et al. (1992, 1993) and Soto et al. (1998) correlated fallout deposits spread over $>100 \mathrm{~km}^{2}$ around Arenal. The thickness of each tephra layer and the dimensions of the 5 largest clasts were measured at each section. Most selected tephra sections were in elevated and flat areas in order to obtain the highest number of tephra-fall layers. Nevertheless, pyroclastic flow and surge deposits were studied in some proximal sites.

Ghigliotti et al. $(1992,1993)$ exhaustively studied the stratigraphy of the tephras of the last three millennia. The distributions of tephras were mapped, and some of the tephras were dated using the ${ }^{14} \mathrm{C}$ method. It had been previously thought that the layer called ET-9, which is underlain by a humic dark paleosol (dated $\sim 3000$ B.P.) with a regional distribution, was the base of Arenal's eruptive sequence (Melson, 1982, 1984; Borgia et al., 1988). A tephra package below the dark soil was mentioned by Melson (1982) hypothesizing that it belonged to the neighboring Chato volcano. Soto et al. (1998) concluded that these layers were from Arenal based on tephra distributions and the presence of interbedded ballistic bombs and blocks in sags near Arenal.

Melson $(1982,1984)$ had introduced the nomenclature "ET- $x$ " for tephra-fall layers, from ET-1 for the most recent, to ET-9 for the oldest. Ghigliotti et al. (1992, 1993) and Soto et al. (1998) used the following numbers to ET-16, and modified Melson's nomenclature to accommodate previously undescribed layers (i.e. ET-8B or ET-9N). We consider it more convenient to use a new nomenclature "AR-x", with an increasing numerical order from the oldest known deposits to the most recent one, in stratigraphical order. We label tephras in figures and tables with the "ET- $x$ " label in brackets for easy correlation to the older literature.

\section{The stratigraphic basement of Arenal}

Above the lateritic soil atop the regional volcanic basement are a number of tuffs underlying the tephras from Arenal. The excavation for the Sangregado Dam foundation $(6 \mathrm{~km}$ northwestward from Arenal: ICE, 1975, 1977), unearthed a lower tuff of unknown origin with quartz and pumice with wood fragments that were dated at $20,850 \pm 800$ B.P. Similar tuffs in a swampy deposit $11 \mathrm{~km}$ westward from Sangregado site were also dated by Melson et al. (1986) at 21,790 \pm 360 B.P. An ash flow tuff found on the northern uprisen flank of Arenal has a charcoal-rich base dated at $>32,000$ B.P. (Soto et al., 1998). This deposit appears to have erupted from Chato or Los Perdidos. Therefore, it seems that Arenal is not older than $22 \mathrm{ka}$. Melson and Sáenz (1973) also had proposed a maximum age of $\sim 20 \mathrm{ka}$ for Arenal. A log from a fluvio-lacustrine deposit below the regional dark paleosol on banks of the Arenal river has been dated at $\sim 4500$ B.P. (Table 1), suggesting that Arenal began erupting after this. Nevertheless, new radiocarbon data date Arenal's oldest tephras at $\sim 7 \mathrm{ka}$, overlying a similar epiclastic sequence.

\section{Stratigraphy}

Unit AR-1 is a tephra deposit that appears to represent the known stratigraphic base of Arenal. At section 80 it is a $17.5 \mathrm{~m}$-thick explosive tephra sequence, corresponding to a single pluri-phase event (Fig. 2). It is underlain by proximal fluvial and epiclastic materials. From bottom to top, AR-1 is composed of: (a) a block and ash flow (thickness: $1 \mathrm{~m}$ ), with gray $\left(\mathrm{SiO}_{2} \sim 62 \%\right.$; silica data hereafter are from Bolge et al., this volume, and/or unpublished data) dense subangular juvenile clasts $(<15 \mathrm{~cm})$, rare andesitic and altered lithics $(<5 \%,<30 \mathrm{~cm})$, in a matrix with abundant organic matter and carbonized trunks; (b) a sequence of light gray pyroclastic surges and flows with cm-to-mm scale laminations and accretionary lapilli (7 m); (c) a gray to pink indurated tuff with isolated

Table 1

Radiocarbon ages of Arenal and Chato tephras, calibrated after Stuiver et al. (1998)

\begin{tabular}{llcl}
\hline Layer & Reference & $\begin{array}{l}{ }^{14} \mathrm{C} \text { age } \\
\text { (B.P.) }\end{array}$ & $\begin{array}{l}\text { Calibrated age } \\
(\text { B.P. }) \pm 1 \sigma\end{array}$ \\
\hline AR-21 [UN-10] & Soto et al., 2000 & $490 \pm 80$ & $520 \pm 30$ \\
AR-21 [UN-10] & $\begin{array}{l}\text { Melson and Sáenz, } \\
\text { 1973 }\end{array}$ & $425 \pm 25$ & $500+10-20$ \\
AR-20 [ET-2] & Sheets, 1984 & $570 \pm 30$ & $550+70-10$ \\
AR-19 [ET-3] & Borgia et al., 1988 & $870 \pm 50$ & $890 \pm 170$ \\
AR-19 [ET-3] & Soto et al., 1998 & $1076 \pm 94$ & $970+100-40$ \\
AR-15 [ET-7] & Ghigliotti et al., 1993 & $1400 \pm 110$ & $1300+110-90$ \\
AR-13 [ET-8B] & Ghigliotti et al., 1993 & $1620 \pm 110$ & $1520 \pm 160$ \\
AR-12 [ET-9N] & Ghigliotti et al., 1993 & $2140 \pm 80$ & $2120+180-120$ \\
AR-10 [ET-9B] & Ghigliotti et al., 1993 & $2280 \pm 90$ & $2330+20-180$ \\
AR-9 [ET-9] & Borgia et al., 1988 & $2895 \pm 145$ & $2990+250-170$ \\
AR-9 [ET-9] & Borgia et al., 1988 & $3025 \pm 150$ & $3210+170-250$ \\
AR-9 [ET-9] & Alvarado, 1989 & $3320 \pm 215$ & $3490+340-150$ \\
Last from Chato & Borgia et al., 1988 & $3460 \pm 70$ & $3700+130-70$ \\
Last from Chato & Borgia et al., 1988 & $3500 \pm 50$ & $3730+90-40$ \\
Last from Chato & Borgia et al., 1988 & $3510 \pm 120$ & $3730+190-100$ \\
Below AR-9 & ICE, 1977 & $4030 \pm 150$ & $4470+350-180$ \\
AR-1 & Soto et al., 1998 & $6150 \pm 120$ & $7010+170-130$ \\
\hline
\end{tabular}


lithics and accretionary lapilli (pyroclastic flow and surge deposit?, $5.5 \mathrm{~m}$ ); and (d) a reddish-brown tuff with abundant accretionary lapilli, some internal structures and isolated lithics $(5 \mathrm{~m})$. The calibrated age of one of the trunks in layer a, is $7010+170-130$ B.P. (Table 1).

The base of Unit AR-2 [ET-16] is an indurated ash, overlain by two layers of fine gray ash and a normallygraded fall deposit of altered juveniles and lithics. The top is a well-developed brown clayish soil, in sections 61 and 80 (Fig. 2).

Unit AR-3 [ET-15] is a hornblende bearing pumicefall deposit $\left(\mathrm{SiO}_{2} \sim 54 \%\right)$, rich in large altered lithics and hornblende cumulates. Ash-rich layers are dispersed throughout.

At sections 61, 79, 80 and 83 (Fig. 2), the base of Unit AR-4 [ET-14] is a gray fine ash, overlain by a fall deposit with crude reverse grading. It is composed of weathered gray scoriae $\left(\mathrm{SiO}_{2} \sim 53 \%\right)$, and hydrothermally altered lithics. It is overlain by a moderately developed brown soil, containing reworked materials and other deposits from minor eruptions.
The base of Unit AR-5 [ET-13] is a fine ash, overlain by an ash-fall deposit, and a lapilli-fall deposit $\left(\mathrm{SiO}_{2} \sim 51-54 \%\right)$. Both fall deposits have hydrothermally altered lithics. The juvenile clasts have mingled silicic and mafic lavas. It is well exposed at sections 45, 61, 79, 80 and 83 (Fig. 2).

Unit AR-6 [ET-12] has alternating layers of lapilli and ash $\left(\mathrm{SiO}_{2} \sim 50-56 \%\right)$, some with normal grading. Fresh lithics of andesitic lavas and diorites can be found. It is well exposed in sections 45, 61, 79, and 80 (Fig. 2). A brown mildly developed soil overlies this layer.

Unit AR-7 [ET-11] consists of two layers of gray ash to lapilli $\left(\mathrm{SiO}_{2} \sim 51-59 \%\right)$. A weakly developed brown soil tops this layer. It is present in sections $45,61,79$ and 82 (Fig. 2). In section 82, AR-7 overlies a pyroclastic flow and a fine coignimbritic ash from the last eruption of Chato volcano, which age is constrained by three ${ }^{14} \mathrm{C}$ ages on carbonized trunks in the pyroclastic flow: an average calibrated age of $3720 \pm 150$ B.P. (cf. Table 1). Therefore, AR-7 and AR-8 were erupted between $\sim 3.7 \mathrm{ka}$ and $\sim 3.2 \mathrm{ka}$ (the age of AR-9, see discussion below).

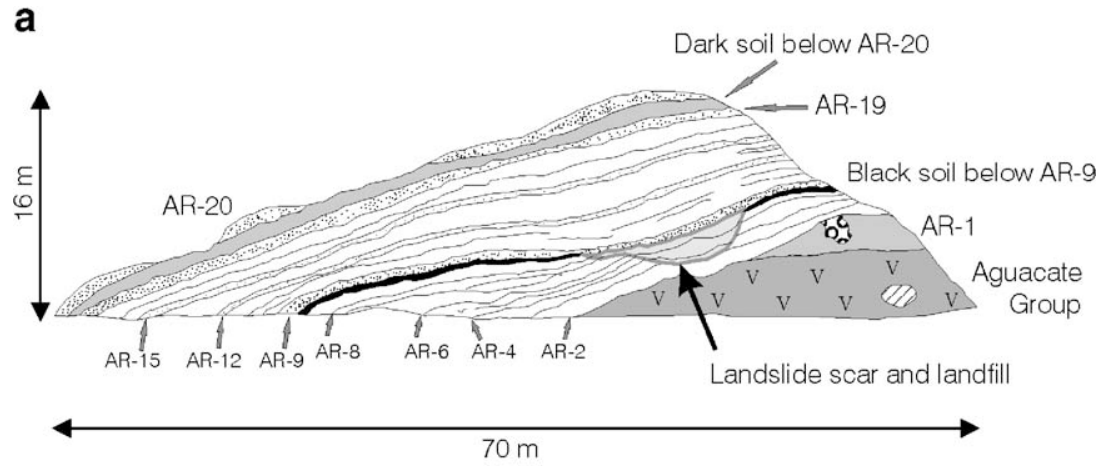

b

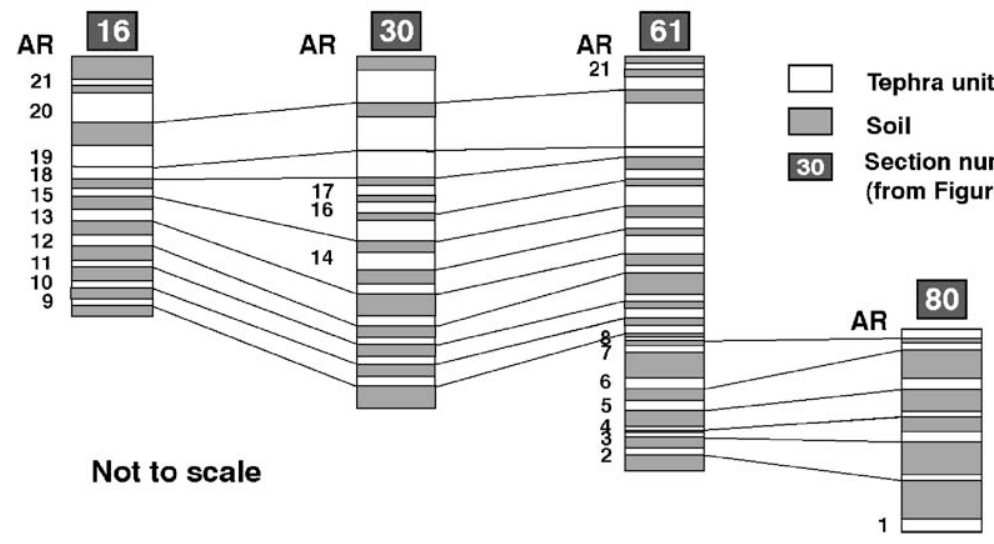

Fig. 2. (a) An example of the tephra sequence: section 84, $6 \mathrm{~km}$ westward from Arenal, on the eastern embankment of Sangregado Dam. b) Example of correlation between tephra units along some measured sections shown in Fig. 1 (modified from original sections in Ghigliotti et al., 1992, 1993; Soto et al., 1998). 
Unit AR-8 [ET-10] is well represented in sections 35, $45,61,79$ and 80 (Fig. 2). Its base is an indurated gray ash deposit with isolated scoriae. Its top is a series of alternating layers of orange to yellow-stained scoriaceous lapilli and ash $\left(\mathrm{SiO}_{2} \sim 50-55 \%\right)$.

Unit AR-9 is the equivalent of ET-9, which was formerly thought to be the base of Arenal's tephra layers (Melson, 1982). This unit overlies a prominent regional black paleosol. The base of this unit is a pinkish-gray indurated ash, which is overlain by a massive moderately sorted lapilli-fall deposit composed by gray to yellow pumice $\left(\mathrm{SiO}_{2} \sim 58 \%\right.$, Borgia et al., 1988) with hydrothermally altered lithics $(5-15 \%)$. The top of the unit consists of indurated coarse ash to fine lapilli, with accretionary lapilli and visible interparticular vesiculation. A well developed black paleosol tops the layer. The three radiocarbon ages shown in Table 1 were obtained from the black paleosol underlying AR-9. The calibrated ages range from $\sim 3.0$ to $\sim 3.5 \mathrm{ka}$, averaging $\sim 3.2$ ka.

The base of Unit AR-10 [ET-9B] is a gray pumice-fall deposit with $10-20 \%$ lithics and symmetrical reverse to normal grading. It is overlain by a fine lapilli and a gray indurated ash with isolated scoriaceous juvenile clasts $\left(\mathrm{SiO}_{2} \sim 52 \%\right)$. The top of the layer is an orange-brown paleosol developed in a gray ash layer. In distal sections (i.e., section 16) it is a single stratified lapilli layer. The minimum calibrated age of this unit is $2330+20-180$ B.P. (Table 1), based in a ${ }^{14} \mathrm{C}$ age of the uppermost underlying organic soil in section 16 (Fig. 2).

The base of AR-11 [ET-9A] consists of fine black scoriaceous coarse ash to lapilli. This is overlain by alternating thin layers of ash and fine lapilli. The unit is capped by a gray, indurated and vesiculated ash, topped by a sequence of thin laminae of scoriaceous lapilli, and ash $\left(\mathrm{SiO}_{2} \sim 51-56 \%\right)$. In distal sections (i.e., section 16), this unit appears only as a muddy indurated gray ash with some scoriaceous lapilli. The fine indurated ash suggests a pronounced phreatomagmatic component during this eruption.

AR-12 [ET-9N] is a massive well-sorted lapilli-fall deposit $\left(\mathrm{SiO}_{2} \sim 60-63 \%\right)$. In sections located to the southwest from Arenal, the upper part is made up of a fine to very fine ash. Gray and hydrothermally altered lithics, including intrusive rocks, are relatively abundant (10$20 \%$ ). In sections on the west and southwest of the volcano, AR-12 is underlain by a black paleosol. The maximum age of this unit is given by a calibrated age of $2120+$ 180-120 B.P. (Table 1), for the top of the underlying black soil in section 16. In this same section, fragments of "Bocana type" pre-Columbian pottery were collected, corresponding to the most antique Arenal Phase ceramic with an age of approximately 300 B.C. (F. Corrales, written com., 1992).

The base of unit AR-13 [ET-8B] consists of a wellsorted fine lapilli-fall deposit $\left(\mathrm{SiO}_{2} \sim 55 \%\right)$ of dark gray scoriae, with a few hydrothermally altered lithics. It is overlain by a fall deposit of coarse lapilli and ash with intercalations of yellowish fine lapilli. The top is an indurated ash with light brown fine lapilli, scoriaceous lapilli and accretionary lapilli, with interparticular vesiculation. In some sections, this unit is capped by an indurated ash with accretionary lapilli and black coarse scoriae on top. The calibrated age for AR-13 is $1520 \pm 160$ B.P. (Table 1), obtained from a charcoal in section 16, associated with pottery fragments immediately underlying the deposit. This suggests that the population suddenly abandoned their settlement because of the eruption. The archaeological age for the pottery corresponds to the Late Arenal Phase (0-500 A.D.) and the beginning of the El Silencio Phase (600-1,000 A.D.), suggesting an age of around 400 A.D. (1550 B.P.; written com., F. Corrales, 1992).

In proximal stratigraphic sections, unit AR-14 [equivalent to ET- 8 by Melson (1982) and ET-8M by Ghigliotti et al. (1993)] is separated from AR-13 by a thin gray scoriaceous lapilli-fall deposit from a minor eruption. This deposit is characterized by layered black scoriaceous lapilli $\left(\mathrm{SiO}_{2} 51-52 \%\right)$, with scarce lithics. The top of this layer is an indurated and vesiculated gray muddy ash, probably from a phreatomagmatic phase.

Unit AR-15 [ET-7] is a massive pumice lapilli deposit $\left(\mathrm{SiO}_{2} \sim 56-61 \%\right)$ overlying a well developed dark brown paleosol. In proximal sections, there is a fine interbed around a quarter up from the base that separates inverse grading at the base from a normally-graded top. Lithics (20-30\%) are concentrated near the top and largely consist of hydrothermally altered and cognate intrusive clasts. In section 34, there is a $30-\mathrm{cm}$ pyroclastic flow deposit on top of the fall deposit. In section 16, a sample of the uppermost part of the underlying soil yielded a calibrated radiocarbon age of $1300+110-90$ B.P. (Table 1).

A thin brown paleosol underlies unit AR-16 [ET-6]. The basal part of this unit is a fine lapilli-fall $\left(\mathrm{SiO}_{2} \sim 51-\right.$ $53 \%$ ) of well-sorted black to red and white scoriaceous fragments with a weak reverse grading. It is overlain by a series of thin laminae of accretionary lapilli, aggregated accretionary lapilli, scoriaceous lapilli and a vesiculated tuff. The top is a well-sorted layer of scoriaceous lapilli with gray and hydrothermally altered lithics $(\sim 5 \%)$, overlain by an indurated vesiculated ash and fine lapilli with isolated scoriae.

Unit AR-17 [ET-5] overlies a poorly developed brown paleosol. In section 32 (Fig. 2), there are ballistic blocks up to $12 \mathrm{~cm}$ across at the base of AR-17. 
Otherwise, the lower part of AR-17 is composed of a horizon of gray pumiceous normally-graded and poorly sorted lapilli and ash fallout deposit $\left(\mathrm{SiO}_{2} \sim 60-62 \%\right)$, with $\sim 10 \%$ andesitic and hydrothermally altered lithics concentrated at the base. This lower lapilli-fall sublayer is associated with a pyroclastic flow and surge sequence in sections 7, 32, 41 and 46. It is overlain by another ash and gray lapilli deposit, mainly to the west. Another poorly sorted and normally-graded pumice and ash fall deposit tops the sequence $\left(\mathrm{SiO}_{2} \sim 56-58 \%\right)$. The archaeological age of this layer is around 700-800 A.D., according to Melson (1982).

Unit AR-18 [ET-4] is composed of numerous fall layers that overlie a brown paleosol. The basal layer consists of gray pumice and some darker and light-dark mingled fragments. It is well-sorted, normally-graded but with a coarser top, with few lithics $(\sim 5 \%)$. There are pyroclastic flow and surge deposits in sections 31,32 and 41 , up to $1 \mathrm{~m}$ thick. In proximal sections, the basal layer is capped by a thin gray ash, a pumice-fall deposit and another thin ash layer. They are overlain by another pumice-fall deposit, finer in the middle, and then a thin accretionary ash. Above these layers are alternating layers of pumiceous lapilli, black scoriae lapilli, and agglutinated accretionary lapilli. Around Los Lagos, on the north flank of the volcano, the basal deposits contain large ballistic blocks. In section 81, the top of AR-18 is made up of lapilli with light and dark banding, becoming darker and more scoriaceous upwards.

Unit AR-19 [ET-3] is characterized by alternating centimeter-scale sublayers of scoriaceous coarse to fine lapilli and ash. Melson (1984) indicated that "ET-3" had a lower section of basaltic lapilli and a top of yellowishbrown ash. In the most proximal and best studied section (81, Fig. 3), the thickness of AR-19 reaches $14 \mathrm{~m}$ (Soto et al., 2000). This section, over $200 \mathrm{~m}$ long, was

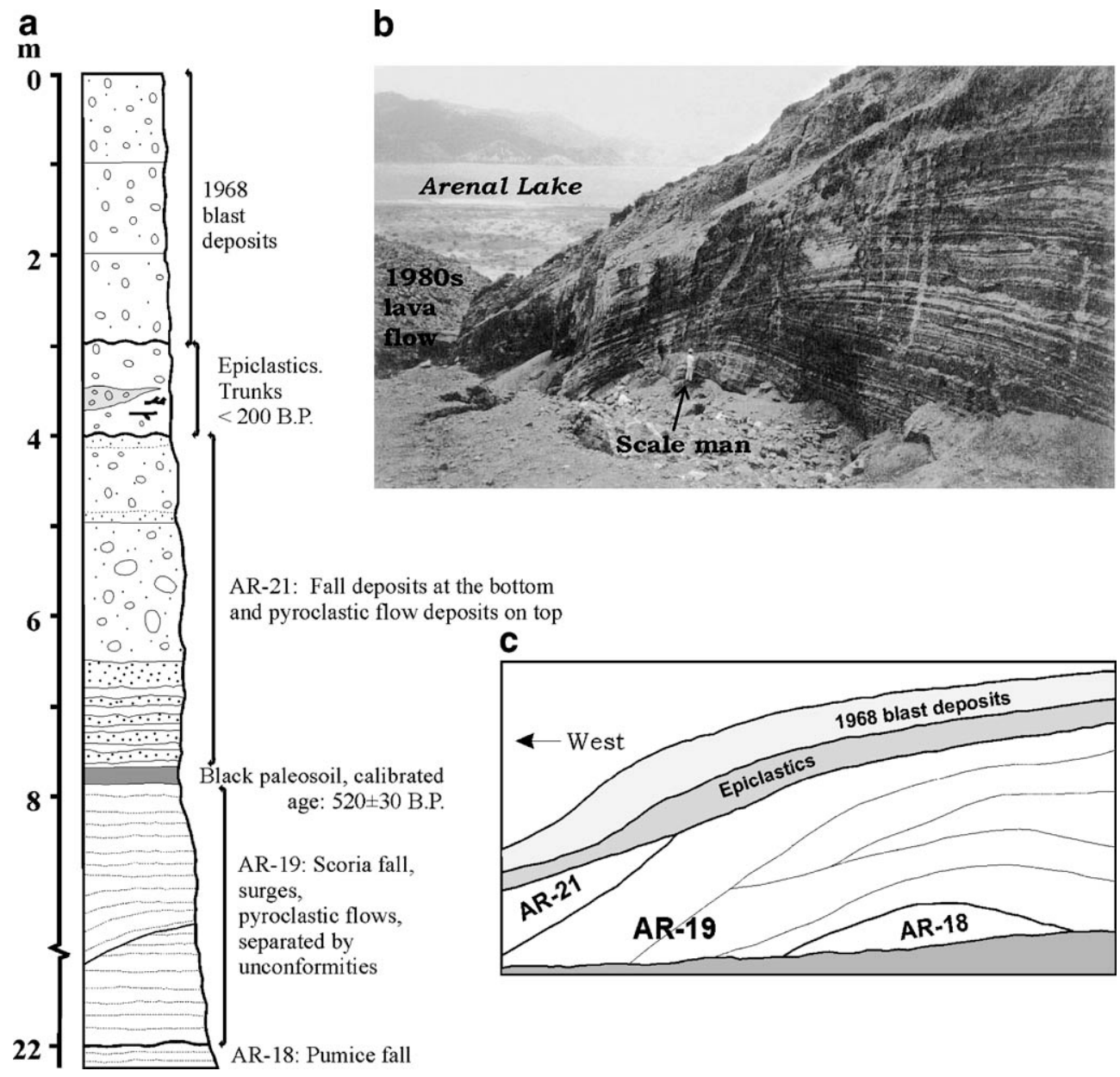

Fig. 3. Section 81 (UTM coordinates $271.5 \mathrm{~N}-457.8$ ) $1.7 \mathrm{~km}$ west from the active crater. (a) simplified stratigraphic column. (b) The section looking westward, showing mostly the AR-19 deposits. The darker strata are scoria fall and the lighter ones are ash fall and surges. The internal and the upper unconformities are well recognized, as the sketch for the whole outcrop in (c) is showing. 
exhumed by erosion during the late 1980s and early 1990s, before it was covered by a lava flow in July 1995 . The lowermost $3.5 \mathrm{~m}$ consisted of fallout lapilli, bombs and ash. This was overlain by an unconformity, beds of fine to medium ash, another unconformity, layered ashfall, pyroclastic flow and surge deposits, a third unconformity, surge deposits and fine ash-fall layers with numerous scoriaceous bombs and dense andesitic blocks, a fourth unconformity and layered lapilli and ash with abundant hydrothermally altered lithics.

In less proximal section 30, it reaches $2.60 \mathrm{~m}$ and is constituted of a lower part $(1.20 \mathrm{~m})$ with at least 40 alternating centimeter-scale layers of lapilli $\left(\mathrm{SiO}_{2} \sim 49-53 \%\right)$ and fine ash. The upper part $(1.40 \mathrm{~m})$ is made up of thin layers of ash, accretionary lapilli, and some scoriaceous lapilli. A poorly developed brown paleosol separates AR19 and AR-20. Other proximal sections have large ballistic blocks and bombs, and pyroclastic flows. The best known section is in the Quebrada Guillermina quarry (presently renamed "Los Laguitos Quarry"), $3 \mathrm{~km}$ northeast from the volcano (UTM coordinates $273.9 \mathrm{~N}-461.1 \mathrm{E}$ ). This location has a pyroclastic flow deposit several meters thick, that is overlain by AR-19 fall deposits. Some outcrops of the pyroclastic flow consist almost entirely of scoriaceous to breadcrusted bombs, with almost no matrix. Ages from carbonized trunks at this location, yield $890 \pm 170$ B.P. and $970+100-40$ B.P. (Table 1), averaging 930 B.P. for the time of this eruption.

Unit AR-20 [ET-2 or Unit 20] is one of the most important, recognizable and best exposed units at Arenal, and therefore has been widely studied previously (Melson, 1982, 1984; Mueller, 1984; Chiesa, 1987a,b; Ghig- liotti et al., 1992). It was described by Melson in El Tajo section, and called it ET-2.

It is a typically double-fall deposit of dacitic pumice $\left(\mathrm{SiO}_{2} \sim 62-63 \%\right)$ and lithics (layers $\mathrm{A}$ and $\mathrm{C}$ : Melson, 1984; Chiesa, 1987a,b), separated by a layer of gray cohesive and vesiculated ash (layer B). Layer A is a pumice-fall deposit with reverse grading at the bottom and normal grading at the top and little matrix. The uppermost layer $\mathrm{C}$ is richer in lithics (mostly hydrothermally altered), with a little matrix, reverse grading at the bottom and normal grading at the top, and larger pumice and lithic clasts. Dense pumice of mingled lava with amphiboles $\left(\mathrm{SiO}_{2} \sim 58-62 \%\right)$ are visible in both $\mathrm{A}$ and $\mathrm{C}$ layers. Layer $\mathrm{C}$ is the thickest and the only one present in the distal sections. Westward from the present active crater, flows and surges of this eruption overlie the fall deposits. The most proximal sections have two more thin ash layers at the base (layers A1 and A2 of Chiesa, 1987a,b; Fig. 4).

The finest ash of this layer has calcareous fossil nanoplankton of Mio-Pliocene age (Coccolithus pelagicus and Cruciplacolithus tenuiforatus), indicating the existence of the limestones from the Venado Formation below Arenal (Chiesa, 1998). Other lithoclasts are from volcanic and plutonic rocks (anorthosites and gabbros; Sachs and Alvarado, 1996).

Archaeological fragments recovered from the underlying soil of AR-20 were identified as $<950$ B.P. (J.V. Guerrero, written com., 1992). Other archaeological ages (M. Mueller, oral com., 1991) suggested an age of $\sim 600$ B.P. Sheets (1984) published a ${ }^{14} \mathrm{C}$ age of $570 \pm$ 30 B.P., calibrated by Chiesa $(1987 a, b)$ to $1362 \pm 20$ A.D., and re-calibrated here to $550+70-10$ B.P. (Table 1).

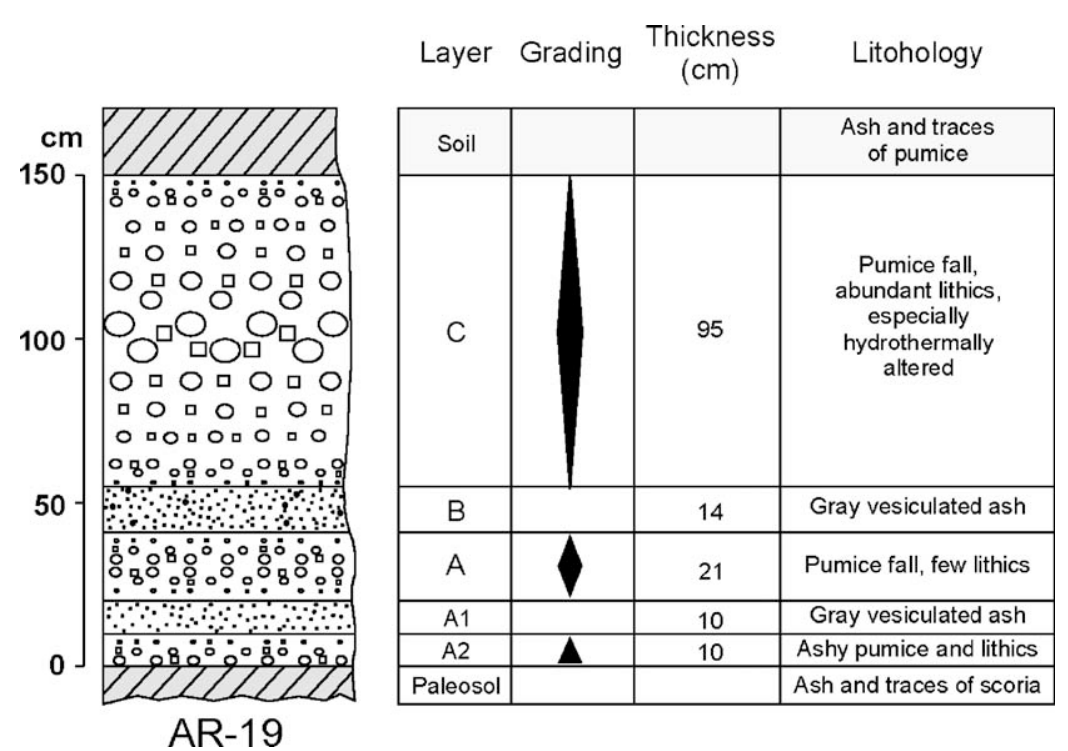

Fig. 4. Complete stratigraphic column of Unit AR-20 exemplified in section 30. 

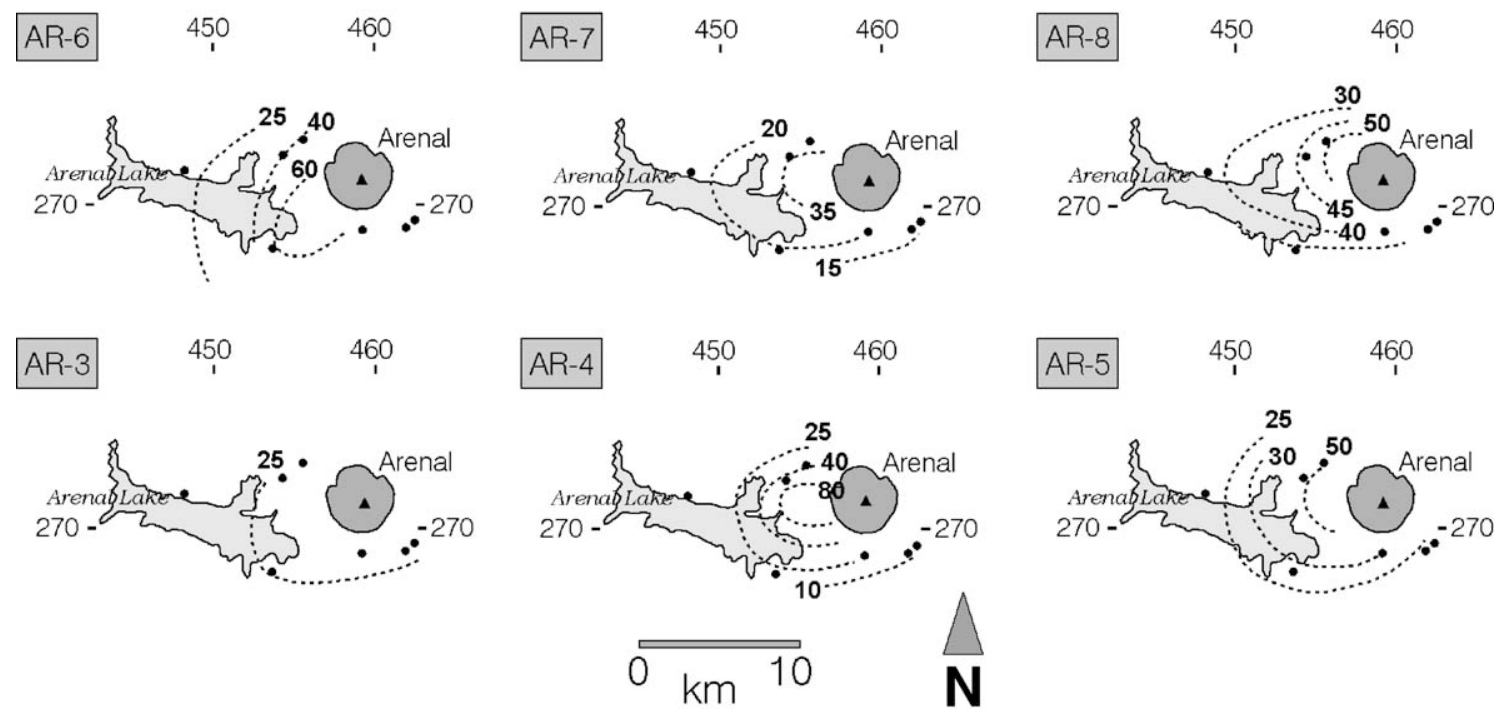

Fig. 5. Approximate isopach maps (in $\mathrm{cm}$ ) for most of the oldest tephra units of Arenal volcano (AR-3 to AR-8). Black dots denote the sections used.

The only significant layer above AR-20 is a rarelyencountered fall deposit of scoriaceous lapilli $\left(\mathrm{SiO}_{2} \sim 53-55 \%\right)$ and ash, overlain by a thick soil. It was called Unit 10 or UN-10 by the archaelogical studies of El Silencio (Mueller, 1984), and now renamed unit AR-21. At section 81 (Fig. 3), fallout deposits are $1.30 \mathrm{~m}$ thick, and are overlain by 2 pyroclastic flows $1.5 \mathrm{~m}$ and $1.0 \mathrm{~m}$ thick. In this section, the underlying soil has a calibrated age of at $520 \pm 30$ B.P. (Table 1). Partially carbonized tree trunks in overlying epiclastic deposits are $<200$ B.P. A radiocarbon age obtained from charcoal in a pyroclastic flow in Quebrada Tabacón and attributed to AR-20 by Melson and Sáenz (1973) was $1525 \pm 20 \mathrm{~A}$. D., which calibrated age is $500+10-20$ B.P. (Table 1 ), and therefore we propose that it corresponds to the eruption AR-21 instead.
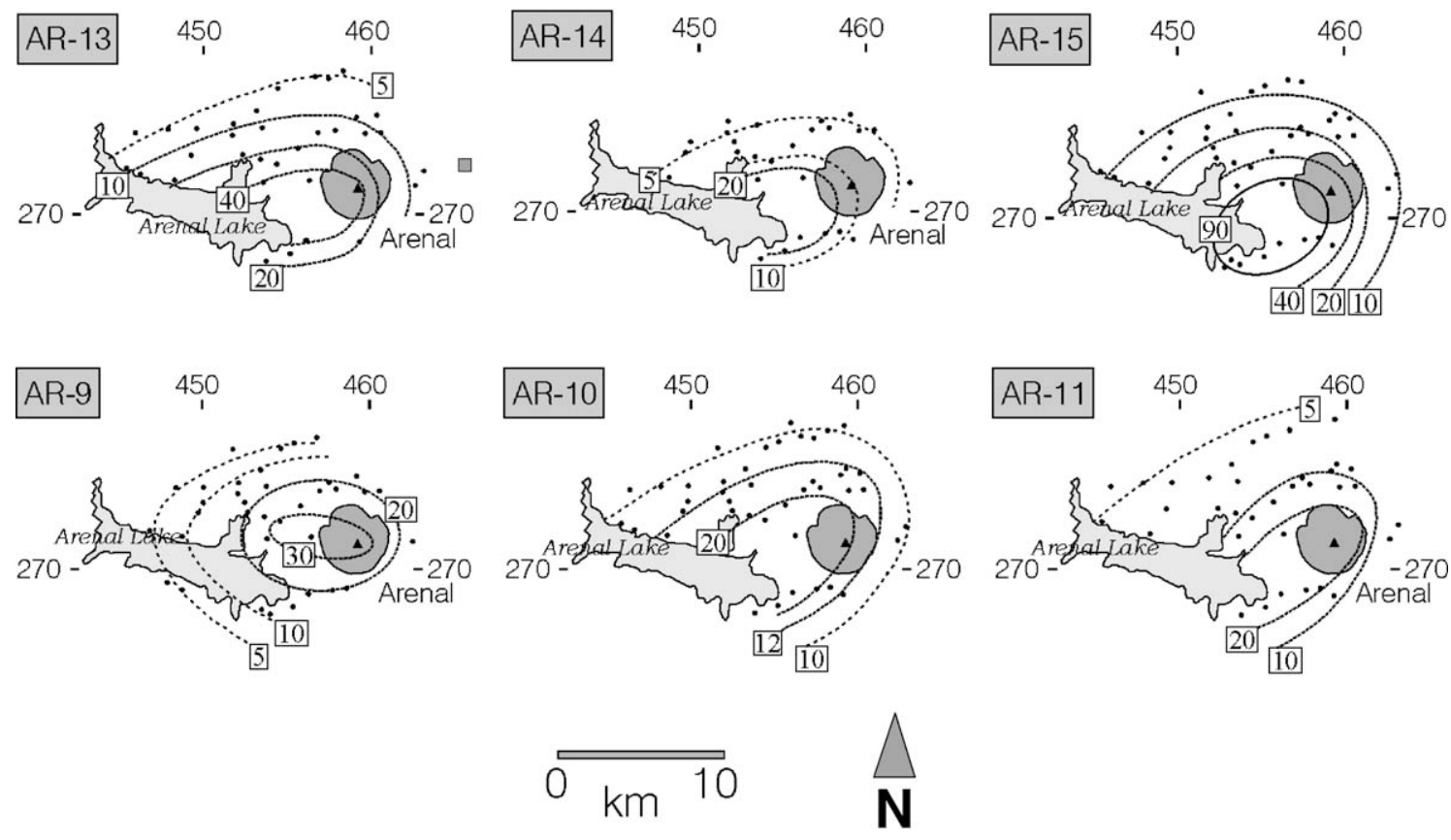

Fig. 6. Isopach maps (in cm) of units AR-9, 10, 11, 13, 14 and 15 (modified from Ghigliotti et al., 1993). Black dots denote the sections used. Solid lines denote well-constrained curves, heavy-dashed lines are mid-constrained curves, and dashed lines are low-constrained curves. 
The fall deposits of AR-22 [ET-1] (July 1968) were studied by Sáenz (1977) immediately after the eruption. He reported thin fall deposits no more than $5 \mathrm{~cm}$ thick near the volcano. On the other hand, the ballistic, flow and surge deposits from July 1968, are preserved on the west flank of the volcano, below the present lava flows. These layers thin from $5.6 \mathrm{~m}$ at the highest available sections, to $10 \mathrm{~cm}$ at the edge of the present Arenal reservoir (Alvarado et al., this volume).

Traces of fall pyroclasts or ballistic blocks and bombs, associated to minor explosive events from Arenal are discontinuously recognized between some of the major units described. These minor layers indicate that eruptions similar in size to AR-22, which are only recognizable in the most proximal sections, have occurred periodically at Arenal. Some examples were observed at section 80, between AR-5 and 6, AR-4 and 5, AR-2 and 3 , and AR-1 and 2. According to obscure reports from the early 20th century, two short explosive events probably occurred in February 1915 and October 1922, but they are not recognizable in the pyroclastic record (Soto et al., 1996).

\section{Tephra distribution, volumes and eruption characteristics}

\subsection{Fallout axes}

Approximate isopachs for the relatively poorly exposed older units AR-3 to AR-8 are shown in Fig. 5. Better constrained isopach maps for AR-9 to AR-15 were drawn by Ghigliotti et al. (1993), and are revisited here (Fig. 6). Scoria isopleths of the basal layer of unit AR-16 show a subcircular dispersion, suggesting a weak wind during its eruption. The isopach map, though, shows a WSW distribution (Fig. 7), perhaps due to a more efficient distribution of the fine ash by the wind.

The aerial distributions of the layers of AR-17 have different patterns due to varying wind directions and velocities during the eruption (Fig. 8). The lower layer has a northward distribution axis, which is unique in Arenal, whereas the upper layer is distributed westward. From the $3.2 \mathrm{~cm}$ isopleth map of lithics $\left(\rho \sim 2.5 \mathrm{~g} \mathrm{~cm}^{-3}\right)$ from the lower layer, the column height was determined from the diagrams of Carey and Sparks (1986) in $\sim 19 \mathrm{~km}$ (subplinian) and a wind velocity $\sim 22 \mathrm{~m} \mathrm{~s}^{-1}$.

According to Melson (1984), each fall layer of AR17 corresponds to a part of a zoned magma chamber, where the basal deposit corresponds to the differentiated top, and the upper fall layer, the more basic lower part of the chamber. They are indeed, two different subplinian pulses in one eruptive cycle.
A detailed stratigraphic geochemical study (Bolge et al., 2004) has shown that AR-18 (Fig. 9) is more siliceous at the bottom $\left(\mathrm{SiO}_{2} \sim 60 \%\right)$ and becomes more basic upwards $\left(\mathrm{SiO}_{2} \sim 55 \%\right)$. There is no paleosol in between AR-18 and AR-19, but an erosional unconformity documents a break into the eruption. In addition, there is also a geochemical break between these two eruption deposits (Bolge et al., 2004).

The proximal sequence of AR-19 reveals that this eruption was developed in several stages, separated by short rests (days, months perhaps) marked by local erosional unconformities. Following AR-18 there was the progressive ejection of a basic magma from the same differentiated magma (Alvarado and Soto, 1997; Bolge et al., 2004). It seems that during the basaltic phase (AR$19)$, the conduit was mainly open and the eruption was mainly violent strombolian. At the end of the first stage, there was a decrease in the energy and some pauses in the eruption (lesser thickness and grain size, and two unconformities). The second phase included pyroclastic flows (e.g. the Quebrada Guillermina flow) and ended with a phreatomagmatic phase and a pause (third unconformity). The third phase was mainly phreatomagmatic, with another pause (fourth unconformity). The last stage erupted numerous surges and abundant hydrothermally altered lithics in the fall deposits, documenting a

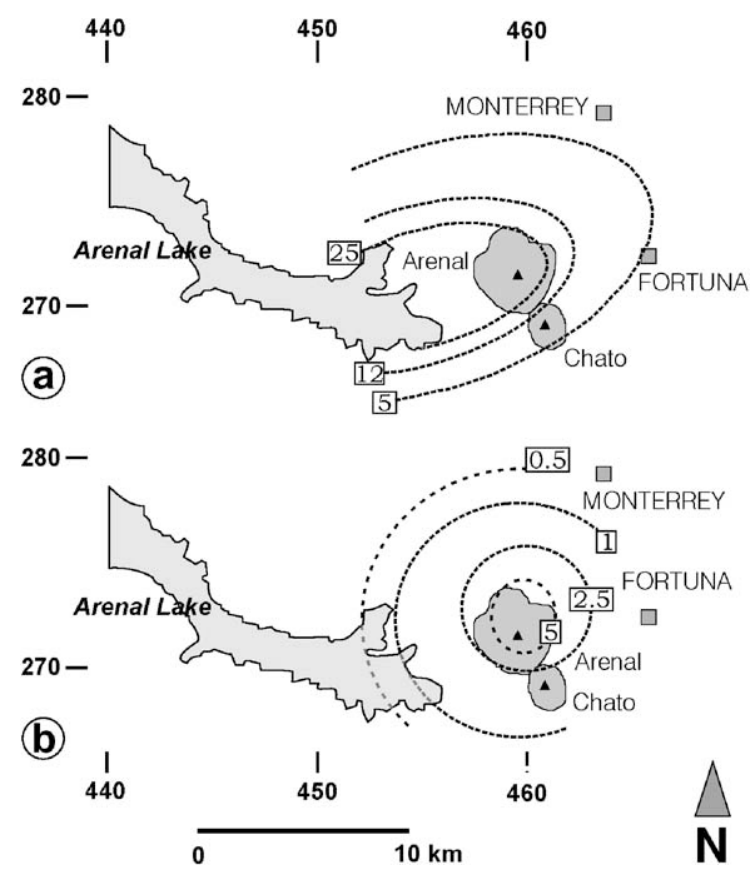

Fig. 7. Unit AR-16: (a) isopachs (in $\mathrm{cm}$ ) for the lower layer. b) Isopleth map (in $\mathrm{cm}$ ) for scoria of the lower layer (modified from Ghigliotti et al., 1993). Heavy-dashed lines are mid-constrained curves, and dashed lines are low-constrained curves. 

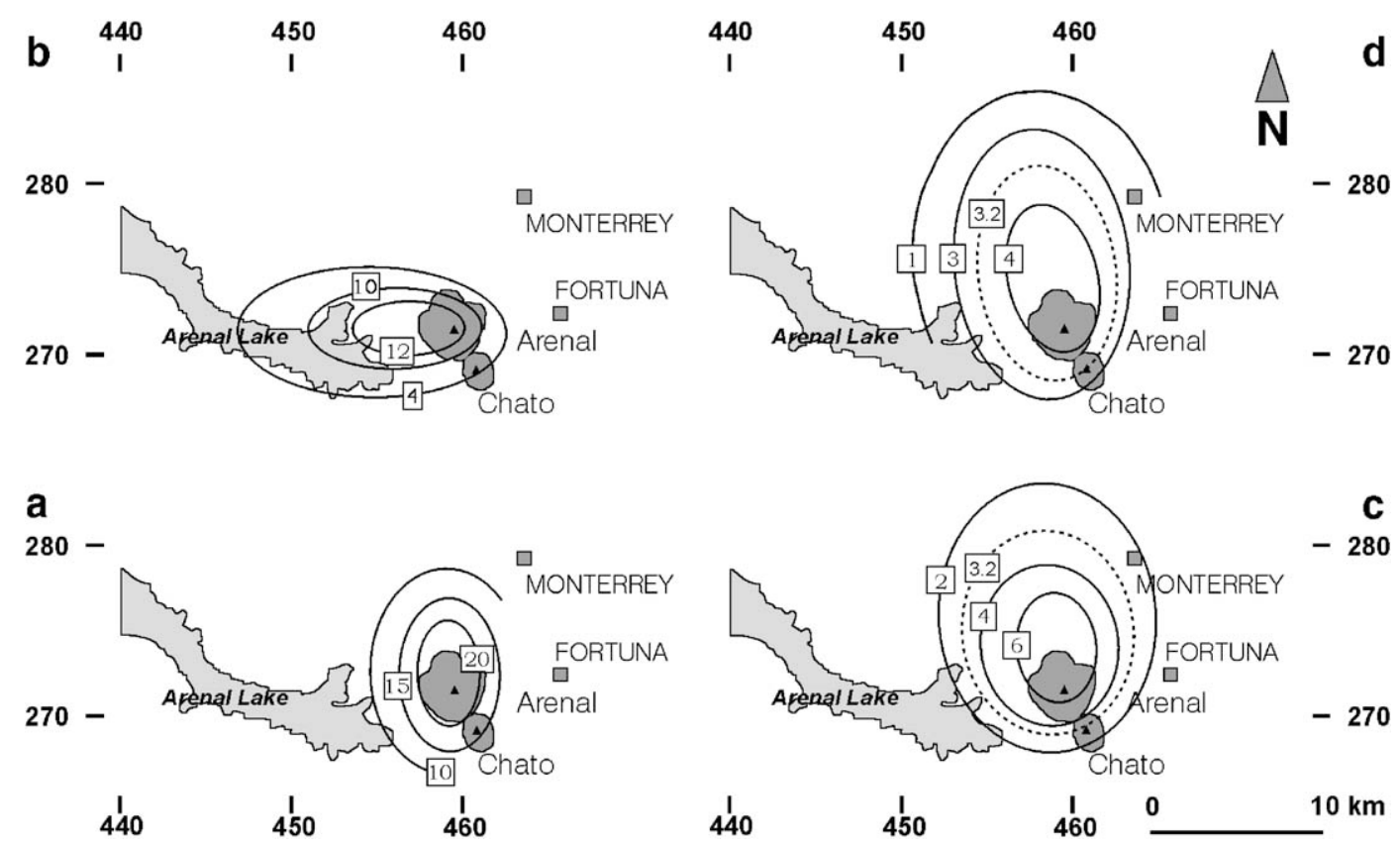

Fig. 8. Unit AR-17: (a) isopachs (in $\mathrm{cm}$ ) for the lower layer: anomalous distribution northward. (b) Isopachs (in $\mathrm{cm}$ ) for the upper layer. (c) Isopleth map (in cm) for lithics of lower layer. (d) Isopleth map (in cm) for pumice of lower layer (modified from Ghigliotti et al., 1993).

phreatomagmatic phase, possibly deepening the fragmentation level into regional aquifers. Energy gradually decreased towards the end of the eruption. The axes of the
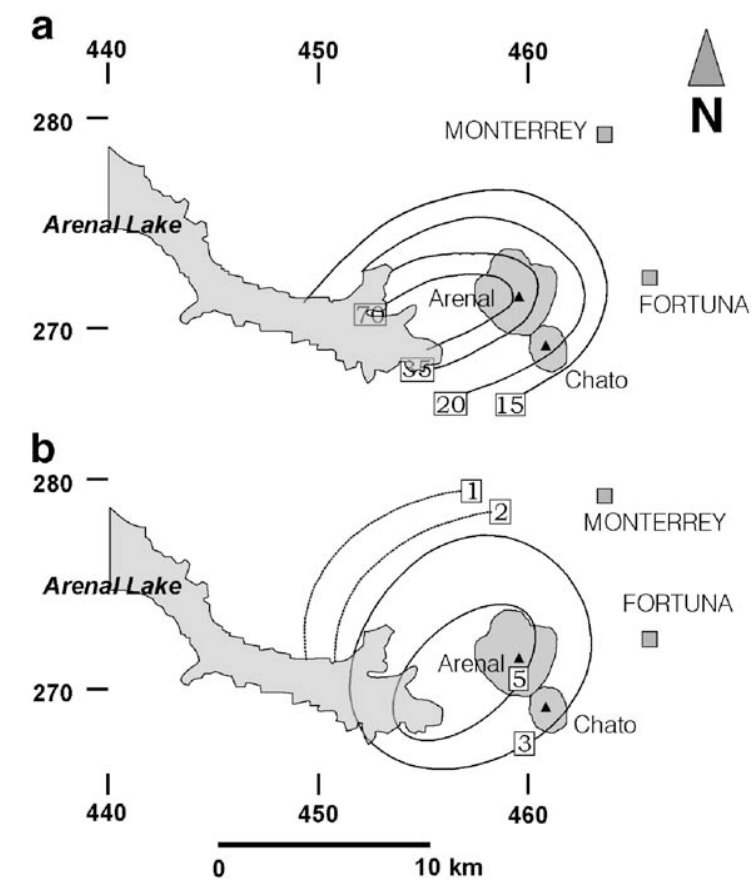

Fig. 9. Unit AR-18: (a) isopachs in $\mathrm{cm}$. b) Isopleths (in $\mathrm{cm}$ ) for pumice (modified from Ghigliotti et al., 1993). isopach and isopleth curves are marginally elongated (Fig. $10 \mathrm{a}, \mathrm{b})$, suggesting the deposition of tephra through weak winds, or for relatively long periods. The large total volume (Table 2) and abundant unconformities support the latter suggestion.

Fig. 10c and d show the smoothed isopach and isopleth maps of unit AR-20 obtained from 52 sections. The different stages of the eruption are documented by the different layers (Fig. 4). The phase corresponding to the $\mathrm{C}$ layer was the most violent and was distributed farther west than other eruptions.

Isopleths for lithics of unit AR-20 (Fig. 11a), are well constrained for diameters larger than $3 \mathrm{~cm}$. Using the $3.2 \mathrm{~cm}$ and $6.4 \mathrm{~cm}$ isopleths for lithics $\left(\rho \sim 2.5 \mathrm{~g} \mathrm{~cm}^{-3}\right.$; Ghigliotti et al., 1992), we have calculated the height of the pyroclastic column for the eruption that deposited layer C, to be $22-24 \mathrm{~km}$ (Fig. 11b), with high intensity winds $\sim 30 \mathrm{~m} \mathrm{~s}^{-1}$, from the east (see Carey and Sparks, 1986). These wind velocities are in accordance with the observations of the eastern trade winds in this latitude, which have maximum velocities of $20-30 \mathrm{~m} \mathrm{~s}^{-1}$ between 23 and $30 \mathrm{~km}$ altitudes (Amador and Alfaro, 1996).

\subsection{Tephra volumes and eruption characteristics}

We have calculated gross tephra volumes for Arenal's tephras, using the formula $V=13.08 T_{0}\left(b_{t}\right)^{2}$ (Pyle, 1989), where $V$ is the total volume of tephra, $T_{0}$ is the maximum 

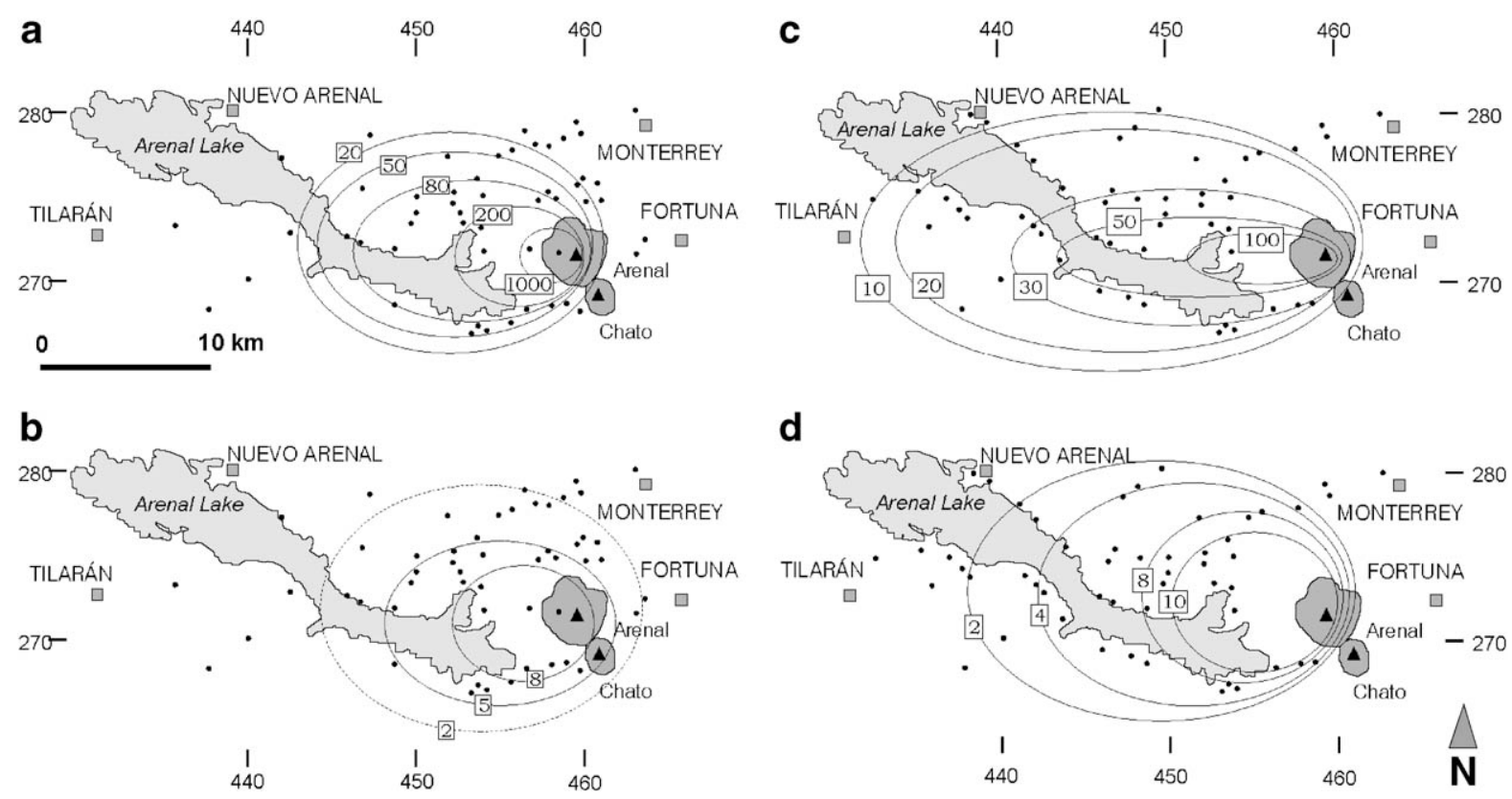

Fig. 10. (a) Isopach map (in $\mathrm{cm}$ ) for unit AR-19. The $1000 \mathrm{~cm}$ isopach is extrapolated from scarce data, mainly from section 81 (Fig. 8). (b) Isopleth map (in cm) for lithics and scoriae of unit AR-19. The $2 \mathrm{~cm}$ curve is approximate. (c) Isopachs (in $\mathrm{cm}$ ) for the whole deposit of unit AR-20. Only layer $\mathrm{C}$ is found beyond some $10 \mathrm{~km}$ westward from the volcano. (d) Isopleths (in $\mathrm{cm}$ ) for pumice from layer C, unit AR-20. Figures modified from Ghigliotti et al. (1992). Black dots denote the sections used. Solid lines denote well-constrained curves, heavy-dashed lines are mid-constrained curves, and dashed lines are low-constrained curves.

theoretical thickness of the deposit extrapolated after plotting the logarithm of isopach thickness versus the square root of the area enclosed by that isopach, and $b_{\mathrm{t}}$ is the square root of the theoretical medium thickness (Table 2). Summing our best estimates for the erupted volume of all of the deposits discussed here, we calculate a total volume of at least $4.5 \mathrm{~km}^{3}$.

VEI indexes (Newhall and Self, 1982) have been assigned to the eruptive units of Arenal (Table 2, Fig. 12), according to isopachs, erupted volumes and compositions, and following the suggestions from Cioni et al. (2000, Table 1) for plinian and subplinian eruptions. Plinian events are qualified relative to AR-20. The term "violent strombolian" is used for those mainly basaltic eruptions with relatively high volumes, resembling but probably lasting longer than subplinian eruptions (see Walker, 1973).

\section{Lava fields}

Most of Arenal volcano edifice is made of blocky lava fields of basaltic andesites. They have been called, from younger to older: A1, A2, A3, A4 and LA ("Lower Arenal") (Borgia et al., 1988; Borgia and Linneman, 1990). According to our nomenclature, we propose to rename them Arenal Lava (ARL) 1 to 5 in stratigraphical order from older to younger (Fig. 12).
ARL 1 [previous LA] appears locally in many sites, where the erosion of the edifice is more intense, and is older than 3200 B.P. It probably includes several lava fields, but can not be precisely correlated because the younger deposits are covering them. ARL 2 [A4] may include lavas from several eruptive episodes. At section 59, these lavas are between AR-9 and AR-10, and therefore have ages between 2300 and 3200 B.P. ARL 3 [A3] are overlain by AR-16 and younger units (in a trench excavated at UTM coordinates $272.2 \mathrm{~N}-461.5 \mathrm{E}$ ), and therefore were erupted $\sim 1250-1300$ B.P. ARL 2 and 3 were erupted from summit central craters in locations similar to the present summit crater, and were later buried by ARL 4 and 5 (Borgia and Linneman, 1990).

According to Borgia et al. (1988), ARL 4 [A2] was probably erupted sometime between 1700 and $1800 \mathrm{AD}$ (18th century). Our correlations suggest they were erupted after 1400 A.D., because they overlie AR 20, but an upper age constraint is not possible to establish according to tephra stratigraphy. The lavas from the ongoing eruption are called ARL 5. Up to late 2004, they have piled up $\sim 0.65 \mathrm{~km}^{3}$. Borgia et al. (1988) considered ARL 2, 3, 4 and 5 [A4, A3, A2 and A1] to have similar volumes around $0.5 \mathrm{~km}^{3}$. Our estimations of the volumes for ARL 3 and younger lavas suggest that they all had volumes comparable to $0.7 \mathrm{~km}^{3}$, for a total of $2.1 \mathrm{~km}^{3}$. ARL 1 and 2 
Table 2

Summary of characteristics of the main Arenal tephra fall eruptions

\begin{tabular}{|c|c|c|c|c|c|c|c|}
\hline Layer & Date B.P. $(0=1950$ A.D. $)$ & Calendar age & Repose period $^{\mathrm{a}}$ (years) & $\% \mathrm{SiO}_{2}$ & Volume $\left(\mathrm{km}^{3}\right)$ & $\mathrm{VEI}^{\mathrm{b}}$ & Eruption type \\
\hline AR-22 [ET-1] & - & 1968 A.D. & 530 & $56-57^{\mathrm{c}}$ & $0.003^{\mathrm{d}}$ & $3^{c}$ & Vulcanian \\
\hline AR-21 [UN-10] & 510 & 1440 A.D. & 40 & $53-55$ & $?$ & $?$ & Vulcanian? \\
\hline AR-20 [ET-2] & 550 & 1400 A.D. & 380 & $62-63$ & 0.44 & 4 & Plinian \\
\hline AR-19 [ET-3] & 930 & 1020 A.D. & 0 & $49-53$ & 0.90 & 4 & Violent strombolian \\
\hline AR-18 [ET-4] & 930 & 1020 A.D. & $270^{\mathrm{e}}$ & $55-60$ & 0.27 & 4 & Subplinian \\
\hline Upper AR-17 [ET-5] & $1200^{\mathrm{e}}$ & 750 A.D. & 0 & $56-58$ & 0.045 & 3 & Subplinian \\
\hline Lower AR-17 [ET-5] & $1200^{\mathrm{e}}$ & 750 A.D. & $50^{\mathrm{e}}$ & $60-62$ & 0.12 & 4 & Subplinian \\
\hline AR-16 [ET-6] & $1250^{\mathrm{e}}$ & 700 A.D. & $50^{\mathrm{e}}$ & $51-53$ & 0.19 & 4 & Violent strombolian \\
\hline AR-15 [ET-7] & 1300 & 650 A.D. & $100^{\mathrm{e}}$ & $56-61$ & 0.38 & 4 & Plinian \\
\hline AR-14 [ET-8M] & $1400^{\mathrm{e}}$ & 550 A.D. & 120 & $51-52$ & $0.15^{\mathrm{f}}$ & 4 & Violent strombolian \\
\hline AR-13 [ET-8B] & 1520 & 430 A.D. & 600 & 55 & $0.20^{\mathrm{f}}$ & 4 & Subplinian \\
\hline AR-12 [ET-9N] & 2120 & 170 B.C. & $100^{\mathrm{e}}$ & $60-63$ & $0.35^{\mathrm{f}}$ & 4 & Plinian \\
\hline AR-11 [ET-9A] & $2220^{\mathrm{e}}$ & 270 B.C. & $110^{\mathrm{e}}$ & $51-56$ & $0.15^{\mathrm{f}}$ & 4 & Subplinian \\
\hline AR-10 [ET-9B] & 2330 & 380 B.C. & 870 & 52 & $0.15^{\mathrm{f}}$ & 4 & Violent strombolian \\
\hline AR-9 [ET-9] & 3200 & 1250 B.C. & $200^{\mathrm{e}}$ & 58 & $>0.13$ & 4 & Plinian \\
\hline AR-8 [ET-10] & $\sim 3400^{\mathrm{e}}$ & 1450 B.C. & $200^{\mathrm{e}}$ & $50-55$ & $0.15^{\mathrm{f}}$ & 4 & Subplinian \\
\hline AR-7 [ET-11] & $\sim 3600^{\mathrm{e}}$ & 1650 B.C. & $600^{g}$ & $51-59$ & $0.15^{\mathrm{f}}$ & 4 & Subplinian \\
\hline AR-6 [ET-12] & $4200^{\mathrm{g}}$ & 2250 B.C. & $550^{\mathrm{g}}$ & $50-56$ & $0.20^{\mathrm{f}}$ & 4 & Subplinian \\
\hline AR-5 [ET-13] & $4750^{\mathrm{g}}$ & 2800 B.C. & $550^{g}$ & $51-54$ & $0.15^{\mathrm{f}}$ & 4 & Violent strombolian \\
\hline AR-4 [ET-14] & $5300^{\mathrm{g}}$ & 3350 B.C. & $550^{\mathrm{g}}$ & 53 & $0.20^{\mathrm{f}}$ & 4 & Violent strombolian \\
\hline AR-3 [ET-15] & $5850^{\mathrm{g}}$ & 3900 B.C. & $550^{\mathrm{g}}$ & 54 & $0.15^{\mathrm{f}}$ & 4 & Violent strombolian \\
\hline AR-2 [ET-16] & $6400^{\mathrm{g}}$ & 4450 B.C. & $610^{\mathrm{g}}$ & - & $?$ & $?$ & $?$ \\
\hline AR-1 & 7010 & 5060 B.C. & - & 62 & $?$ & $4 ?$ & Plinian? \\
\hline
\end{tabular}

a Between major eruptions, since other minor or extrusive ones could have occurred.

b VEI as explained in text.

c Alvarado et al., this volume.

d Sáenz, 1977.

e Approximate interpolation between near known ages of other eruptions.

${ }^{\mathrm{f}}$ Volumes estimated from similar eruptions, according to isopach comparisons.

g Gross interpolation between known ages of other eruptions.

include several lava fields near the core of the volcano, and are probably more voluminous.

\section{Eruptions in function of time}

The volumes and distribution of the tephras older than AR-9 are less well-understood than those erupted during the last 3200 years because of burial and bioturbation. Nevertheless, the stratigraphic data indicate that 8 major explosive eruptions took place between 7000 and 3200 B.P., and 12 major eruptions have taken place since 3200 B.P. (Fig. 12).

The well constrained ages and characteristics of the eruptions from AR-9 to present, allow some patterns of eruption to be established:

i) Plinian events AR-20, AR-15, AR-12 and AR-9 were the most violent and voluminous eruptions of Arenal. These four eruptions are separated from each other by periods of 750, 820 and 1080 years, with a tendency for the quiescent intervals to decrease with time. Therefore, another plinian eruption would be expected about 2100-2200
A.D., if this pattern remains. Borgia et al. (1988) had pointed out about the periodicity of magmabatch emplacement and longevity in $\sim 800$ years.

ii) The largest explosive events at Arenal, represented by tephras AR-20, AR-15, AR-12 and AR-9, were followed by constructive phases and minor explosive phases. Indeed, the longest periods lacking significant explosive activity followed plinian events: AR9 ( 900 years), and AR-12 ( 600 years). The constructive phases are represented by the voluminous lava fields: ARL 2, ARL 3 and ARL 4, which were erupted after AR-9, AR-15 and AR-20, respectively (Fig. 12).

We estimate that the total volume of tephra fall deposits at Arenal to be approximately $4.5 \mathrm{~km}^{3}$, based on the information in Table 2. A gross estimation reveals that nine tenths of tephra fall is deposited out of the volcano edifice, therefore $\sim 4.0 \mathrm{~km}^{3}$ of this tephra must be added to the edifice volume, which is $15 \mathrm{~km}^{3}$. The total erupted volume since $7 \mathrm{ka}$ is $\sim 19 \mathrm{~km}^{3}$, which produces an average eruption rate of $\sim 2.7 \mathrm{~km}^{3} \mathrm{ka}^{-1}$, or 

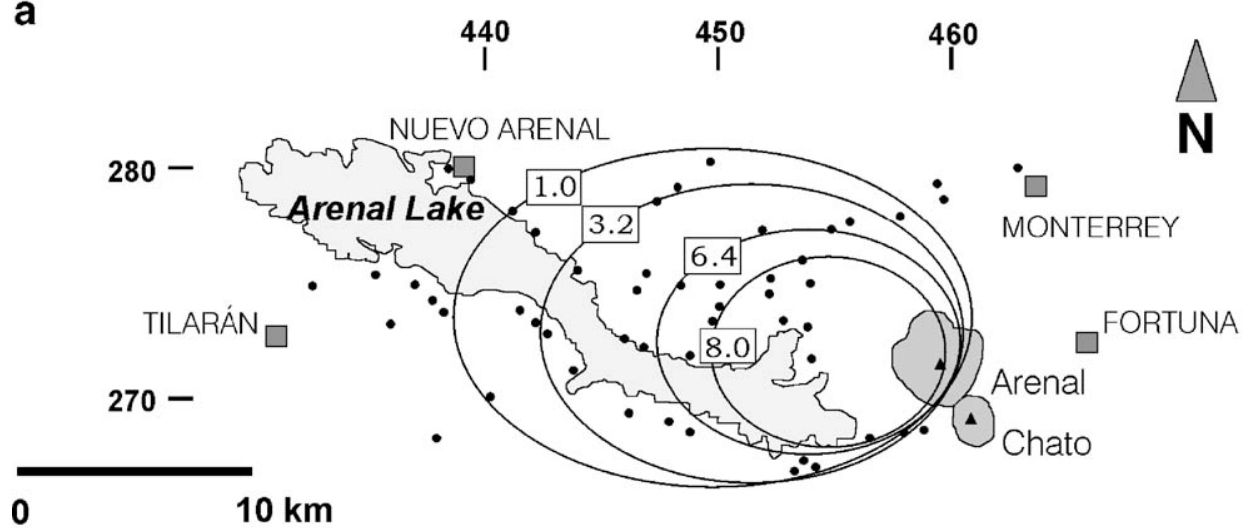

b
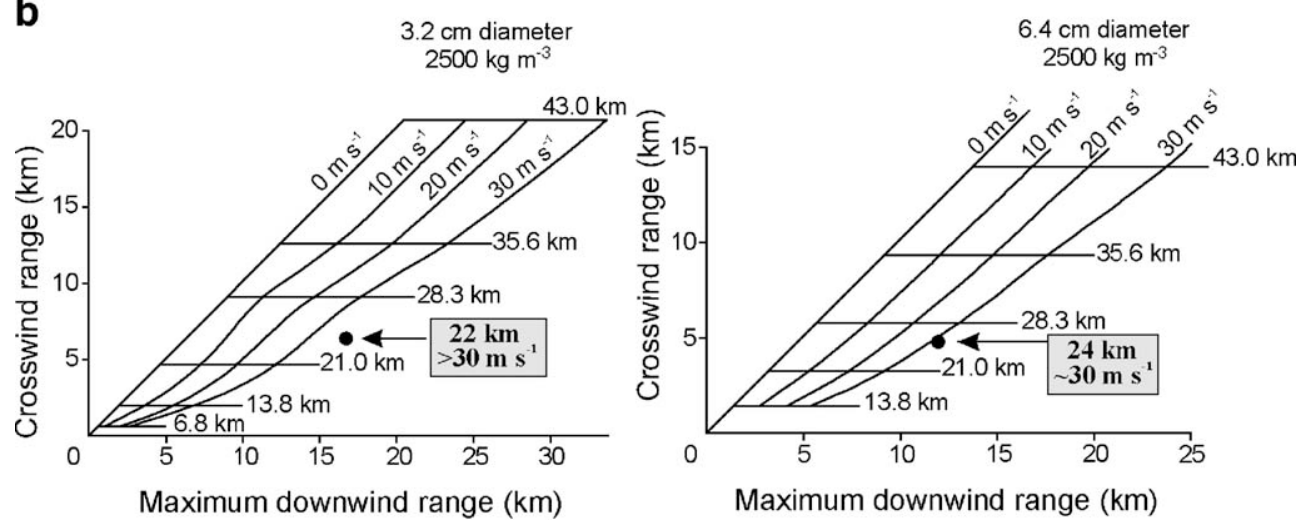

Fig. 11. (a) Isopleth map (in cm) for lithics of AR-20C (modified from Ghigliotti et al., 1992). Black dots denote the sections used. (b) Diagram of Carey and Sparks (1986) and calculation of column height and wind according to data in (a) for the $3.2 \mathrm{~cm}$ and $6.4 \mathrm{~cm}$ lithic isopleths.

$0.086 \mathrm{~m}^{3} \mathrm{~s}^{-1}$. The output of lavas during the last 25 years has been about 4 times this amount $\left(0.32-0.36 \mathrm{~m}^{3} \mathrm{~s}^{-1}\right.$ : Wadge, 1984; Soto and Arias, 1998; Wadge et al., this volume). If half of the edifice is made up of lavas erupted at rates similar to those of this period, then Arenal would have needed only $0.7 \mathrm{ka}$ to erupt such a volume. In other words, Arenal was erupting about one tenth of its entire life.

\section{Why dark paleosols above AR-9 and not beneath?}

The pyroclastic sequence above AR-9 is well preserved and correlatable over a wide area, atop a black paleosol, making it an excellent marker sequence. Other well developed and widespread dark paleosols have been found below AR-15, AR-13, AR-12 and AR-10.

In contrast, tephras AR-1 to AR-8 have no intervening dark paleosols. This does not appear to be related to eruption size or tephra distribution, as these parameters have been relatively consistent at Arenal. These differences in soils also do not appear to be related to the length of repose interval. First, repose periods are generally longer between the older eruptions with intervening lighter soils than for the younger eruptions with the darker soils (Table 2). Second, the dark soils appear to be developed during short and long repose times. For example, the repose period between AR- 8 and AR-9 was $\sim 200$ and not longer than 300 years; between AR-11 and AR-12, 100 years; between AR-12 and AR-13, $\sim 600$ years, and between AR-14 and AR-15, 100 years. This means that developing a dark soil does not need a long period of repose. By comparison, $10-20 \mathrm{~cm}$ of soil has grown in vegetated areas in less than 40 years since the 1968 eruption.

There are two possible explanations for the abundance of dark soils after $3.2 \mathrm{ka}$ but not before: climate change or the presence of anthrosols enriched in organic matter by human activity.

There are little reliable data on paleoclimates in Central America. Markgraf (1989) argues for increased aridity between $6 \mathrm{ka}$ and $5 \mathrm{ka}$ in Mexico, the Central American lowlands and in South America. Others have argued for cycles of dry and humid periods in the tropical Americas through the Holocene (cf. Markgraf and Bradbury, 1982; 

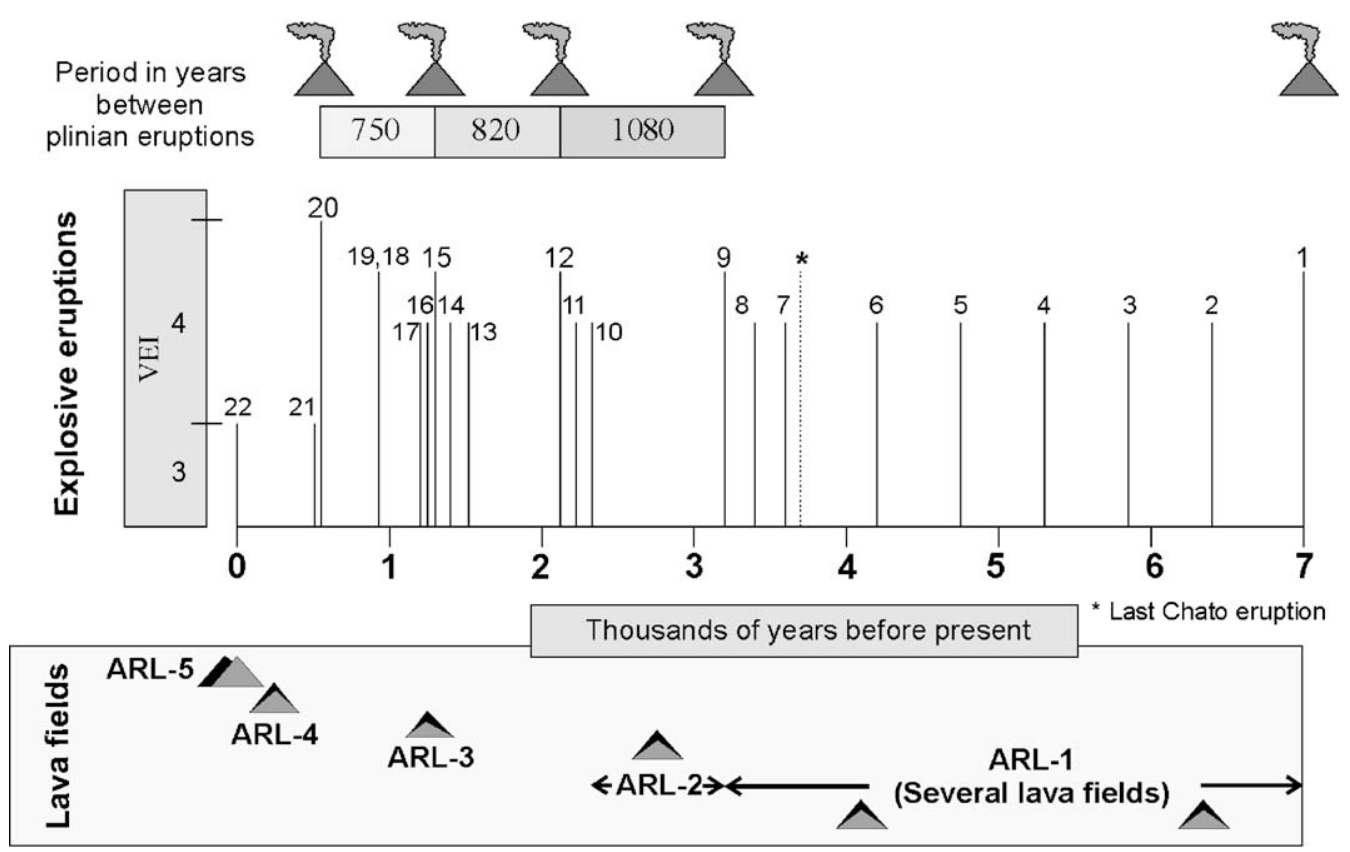

Fig. 12. Eruptive history of Arenal along 7 ka: major explosive and extrusive eruptions.

Street-Perrot and Perrot, 1990; Horn and Sanford, 1992). Snarkis (1984) and Hurtado and Alvarado (1988) used archaeological records to suggest that climate changes urged the Amerindians to switch from being nomadic hunters to sedentary farmers in the Caribbean and northern Pacific areas in Costa Rica at around 3.0 ka. On the other hand, although Sheets et al. (1991) affirm that sedentism had arisen near Arenal at about $4 \mathrm{ka}$, there is no supporting evidence that this was due to climate changes. Therefore, it is not clear whether the climate was arid before 4-3 ka and humid thereafter. Nevertheless, this is the preferred explanation, as a cultural change from nomadic to agricultural cannot explain the regional nature of the change from light to dark soils around Arenal.

\section{Conclusions}

The volcanic history of Arenal has been updated through the reevaluation of tephra-stratigraphic studies, supported with the calibration and discussion of radiocarbon ages. Deposits of major eruptions were renamed AR-1 to AR-22, following a stratigraphic order, from older to younger. These eruptions began at about $7 \mathrm{ka}$, producing tephras that overlie regional tuffs that are $>20000$ years old, as well as older volcanic and sedimentary rocks of Neogene age.

The detailed study of 84 sections has permitted isopach maps to be constructed for most of these fallout deposits, showing that most tephra fall deposits are oriented westward or southwestward, following the trade winds from the Caribbean Sea. The isopleths of the best known tephra fall deposit, AR-20 show that the products of the plinian phase of the eruption were affected by strong winds up to $30 \mathrm{~m} \mathrm{~s}^{-1}$, which have been observed in this latitude at $23-30 \mathrm{~km}$ altitudes. The only anomalously distributed tephra toward the north is the lower layer of AR-17, a subplinian eruption distributed by winds of $22 \mathrm{~m} \mathrm{~s}^{-1}$.

The isopachs have also allowed to calculate volumes of the fall deposits. Plinian eruptions AR-20, AR-15, AR-12 and AR-9, were the most significant, with tephra volumes up to $0.44 \mathrm{~km}^{3}$. These plinian eruptions were separated by periods of 750-1080 years. There were also 8 subplinian eruptions with tephra volumes up to $0.27 \mathrm{~km}^{3}, 7$ violent strombolian eruptions with tephra volumes up to $0.20 \mathrm{~km}^{3}$. AR-19, one of the longestlived and most complex eruptions, deposited $0.90 \mathrm{~km}^{3}$ of tephra. Tens of other minor vulcanian explosive eruptions resembling AR-22, have been recognized as well. The estimated total volume of tephra fall is $\sim 4.5 \mathrm{~km}^{3}$.

Lava cycles have generally followed the plinian eruptions. The lava fields were renamed here as ARL 1 to 5, from older to younger. Typical erupting volumes for these cycles have been in the order of $\sim 0.7 \mathrm{~km}^{3}$. Using the volume of the volcano edifice and the tephra deposits, we calculate an average rate of eruption of $\sim 2.7 \mathrm{~km}^{3} \mathrm{ka}^{-1}$ $\left(0.086 \mathrm{~m}^{3} \mathrm{~s}^{-1}\right)$. 
The tephra sequence previous to AR-9 (3200 B.P.7010 B.P.) has no dark soils, whereas the overlying sequence does. We speculate that this change is the consequence of a regional climatic change from arid to the rainy tropical climate that Arenal has today.

Borgia et al. (1988, p. 103) had written: "we argue that Arenal has probably been active during most of its life". Indeed, Arenal's past behavior (its "volcanality") seems to be quite active, in eruption about one tenth of its complete existence.

\section{Acknowledgements}

This work was enhanced by the project Evaluación del Riesgo y Monitoreo del Volcán Arenal, financed by ICE, in cooperation with Geotermica italiana srl, and concluded by the end of the 20th century. Antonio Frullani, from Geotermica italiana $\mathrm{srl}$, greatly contributed in the early phases of this project, and Marcello Ghigliotti - also at Geotermica - was quite instrumental up to the latest phases of the project, with superb contributions. Louise Bolge kindly provided the silica data of tephra. The assistance by Francisco "Chico" Arias during the fieldwork is highly acknowledged. Jennifer Wade, William Melson, an anonymous reviewer and especially Mark Reagan, made thoughtful comments and suggestions to the manuscript.

\section{Appendix A}

UTM coordinates (local Lambert Costa Rica Norte) of the sections studied around Arenal volcano.

\begin{tabular}{lllllllll}
\hline Section & North & East & Section North & East & Section & North & East \\
\hline 1 & 274.9 & 452.2 & 29 & 273.4 & 435.6 & 57 & 278.7 & 459.1 \\
2 & 275.2 & 452.0 & 30 & 272.0 & 453.4 & 58 & 278.3 & 458.7 \\
3 & 274.3 & 450.0 & 31 & 274.1 & 459.8 & 59 & 273.3 & 462.3 \\
4 & 273.3 & 449.7 & 32 & 274.6 & 458.0 & 60 & 275.8 & 460.8 \\
5 & 272.2 & 447.1 & 33 & 276.0 & 460.0 & 61 & 267.3 & 454.0 \\
6 & 273.9 & 452.4 & 34 & 271.8 & 462.8 & 62 & 275.8 & 443.7 \\
7 & 275.8 & 459.7 & 35 & 267.6 & 460.0 & 63 & 277.4 & 441.7 \\
8 & 282.0 & 464.8 & 36 & 276.8 & 454.7 & 64 & 274.8 & 446.3 \\
9 & 286.5 & 459.4 & 37 & 277.9 & 456.5 & 65 & 275.4 & 447.8 \\
10 & 283.8 & 457.4 & 38 & 278.5 & 459.2 & 66 & 275.5 & 432.4 \\
11 & 281.4 & 451.2 & 39 & 279.7 & 462.9 & 67 & 267.8 & 427.9 \\
12 & 281.2 & 450.6 & 40 & 272.5 & 463.1 & 68 & 275.3 & 437.5 \\
13 & 279.6 & 448.9 & 41 & 274.8 & 457.2 & 69 & 274.3 & 442.3 \\
14 & 278.2 & 447.5 & 42 & 271.3 & 456.8 & 70 & 271.8 & 443.6 \\
15 & 275.4 & 446.6 & 43 & 267.7 & 453.8 & 71 & 270.4 & 446.1 \\
16 & 272.4 & 446.3 & 44 & 268.6 & 458.6 & 72 & 269.5 & 448.1 \\
17 & 274.1 & 452.3 & 45 & 271.8 & 449.4 & 73 & 279.4 & 448.0 \\
18 & 273.9 & 444.8 & 46 & 275.0 & 457.5 & 74 & 280.5 & 449.9 \\
19 & 278.7 & 440.9 & 47 & 268.6 & 458.2 & 75 & 289.0 & 460.5 \\
20 & 279.8 & 439.0 & 48 & 268.7 & 456.2 & 76 & 289.4 & 460.9 \\
21 & 275.9 & 434.2 & 49 & 268.4 & 455.6 & 77 & 277.2 & 451.6 \\
22 & 275.8 & 437.2 & 50 & 267.7 & 453.5 & 78 & 275.1 & 450.1 \\
\hline
\end{tabular}

Appendix A (continued)

\begin{tabular}{lllllllll}
\hline \multicolumn{2}{l}{ Section } & North & East & \multicolumn{2}{l}{ Section } & North & East & \multicolumn{2}{l}{ Section } & North & East \\
\hline 23 & 275.1 & 437.9 & 51 & 273.0 & 450.0 & 79 & 272.2 & 454.0 \\
24 & 274.9 & 440.9 & 52 & 274.4 & 453.9 & 80 & 273.8 & 456.1 \\
25 & 273.8 & 442.8 & 53 & 276.3 & 454.5 & 81 & 271.5 & 457.8 \\
26 & 269.2 & 448.6 & 54 & 275.9 & 453.2 & 82 & 268.0 & 462.1 \\
27 & 270.3 & 440.1 & 55 & 278.2 & 454.9 & 83 & 268.1 & 462.3 \\
28 & 268.7 & 438.1 & 56 & 277.7 & 455.7 & 84 & 272.6 & 453.2 \\
\hline
\end{tabular}

\section{References}

Alvarado, G.E., 1989. Consideraciones neotectónicas recientes en los alrededores de la Laguna de Arenal, Costa Rica. Bol. Obs. Vulcanol. Arenal 2 (3), 6-21.

Alvarado, G.E., 2000. Volcanes de Costa Rica: Geología, historia y riqueza natural. Ed. UNED, 269 pp. (San José).

Alvarado, G.E., Soto, G.J., 1997. Aspectos petrológicos de las tefras del Arenal a la luz de nuevos datos geoquímicos y cronoestratigráficos. Bol. Obs. Sismol. Vulcanol. Arenal Miravalles 7 (13-14), 58-72, 1994, San José.

Alvarado, G.E., Soto, G.J., Schmincke, H.-U., Bolge, L.L., Sumita, M., (this volume). The 1968 andesitic lateral blast eruption at Arenal volcano, Costa Rica. J. Volcanol. Geotherm. Res.

Amador, J., Alfaro, E., 1996. La Oscilación Cuasi-bienal, ENOS y acoplamiento de algunos parámetros superficiales y estratosféricos sobre Costa Rica. Top. Meteorol. Oceanogr. 3 (1), 45-53.

Bolge, L.L., Carr, M.J., Feigenson, M.D., Borgia, A., 2004. Geochemistry and magmatic evolution of explosive tephras ET3 and ET4 from Arenal volcano, Costa Rica. In: Soto, G.J., Alvarado, G. E. (Eds.), La Vulcanología y su entorno geoambiental. Rev. Geol. Am. Cent., vol. 30, pp. 127-135.

Bolge, L.L. Carr, M.J., Feigenson, M.D., Alvarado, G.E., (this volume). The Geochemical and Petrological History of Arenal Volcano, Costa Rica. J. Volcanol. Geotherm. Res.

Borgia, A., Poore, C., Carr, M.J., Melson, W.G., Alvarado, G.E., 1988. Structural, stratigraphic, and petrologic aspects of the Arenal-Chato volcanic system, Costa Rica: evolution of a young stratovolcanic complex. Bull. Volcanol. 50, 86-105.

Borgia, A., Linneman, S.R., 1990. On the mechanisms of lava flow emplacement and volcano growth: Arenal, Costa Rica. In: Fink, J.H. (Ed.), Lava Flows and Domes. Emplacement Mechanisms and Hazard Implications. IAVCEI Proceedings in Volcanology, vol. 2. Springer-Verlag, Berlín, pp. 208-243.

Carey, S., Sparks, R.S.J., 1986. Quantitative models of the fallout and dispersal of tephra from volcanic eruptive columns. Bull. Volcanol. 48, 109-125.

Chiesa, S., 1987a. Estudio de las capas piroclásticas (tefras) del Volcán Arenal (Costa Rica), con énfasis en la Unidad 20. Internal report. ICE, $73 \mathrm{pp}$.

Chiesa, S., 1987b. La mayor erupción pliniana del Volcán Arenal, Costa Rica. Rev. Geol. Am. Cent. 6, 25-41.

Chiesa, S., 1998. Presencia de xenobiolíticos de nanoplanton calcáreo neógeno en tefras plinianas como evidencia de un basamento sedimentario bajo el volcán Arenal. Bol. Obs. Sismol. Vulcanol. Arenal Miravalles 9 (17-18), 1-4 (1996, San José).

Cioni, R., Marianelli, P., Santacroce, R., Sbrana, A., 2000. Plinian and sub- plinian eruptions. In: Sigurdsson, H., Houghton, B., McNutt, S.R., Stix, J. (Eds.), Encyclopedia of Volcanoes. Academic Press, pp. 477-494. 
Ghigliotti, M., Frullani, A., Alvarado, G.E., Soto, G.J., 1992. Distribución areal y características de los depósitos de tefra más recientes (1080-1968 dC) del Volcán Arenal. Bol. Obs. Vulcanol. Arenal 4 (8), 11-33 (San José).

Ghigliotti, M., Frullani, A., Soto, G.J., Alvarado, G.E., 1993. Tefroestratigrafía, historia y ciclos eruptivos del volcán Arenal. Bol. Obs. Vulcanol. Arenal 5 (9-10), 52-96 (San José).

Gillot, P.-Y., Chiesa, S., Alvarado, G.E., 1994. Chronostratigraphy of Upper Miocene - Quaternary Volcanism in Northern Costa Rica. Rev. Geol. Am. Cent. 17, 45-53.

Horn, S.P., Sanford, R.L., 1992. Holocene fires in costa rica. Biotropica 24 (3), 354-361.

Hurtado, L., Alvarado, G., 1988. Datos arqueológicos y vulcanológicos de la región del volcán Miravalles, Costa Rica. Vínculos 14, $77-89$.

ICE, 1975. Gráficos geológicos de perforación y planos de inyección sitio de presa Proyecto Arenal. Internal report ICE, n.p., San José.

ICE, 1977. Informe geológico de progreso al 20 de diciembre de 1976 en la construcción del Proyecto de Arenal. Internal report ICE, 4 tomes + maps, San José.

Malavassi, R.E., 1979. Geology and Petrology of Arenal Volcano, Costa Rica, University of Hawaii, 111 p. (MSc. Thesis).

Malavassi, V.E., Madrigal, R., 1970. Reconocimiento geológico de la Zona Norte de Costa Rica. Dirección de Geología, Minas y Petróleo, Informes Técnicos y Notas Geológicas, IX, vol. 38. 18 pp.

Markgraf, V., 1989. Palaeoclimates in Central and South America since 18000 BP based on pollen and lake-level records. Quat. Sci. Rev. 8, 1-24.

Markgraf, V., Bradbury, J.P., 1982. Holocene climatic history of South America. Striae 16, 40-45.

Matumoto, T., Ohtake, M., Latham, G., Umaña, J., 1977. Crustal structure in Southern Central America. Bull. Seismol. Soc. Am. 67, $121-135$

Melson, W.G., 1982. Alternation between acidic and basic magma in major explosive eruptions of Arenal Volcano, Costa Rica. Bol. Vulcanol., vol. 14. Univ. Nacional, Costa Rica, pp. 65-74.

Melson, W.G., 1984. Prehistoric eruptions of Arenal volcano, Costa Rica. Vínculos 10 (1-2), 34-59.

Melson, W.G., Sáenz, R., 1973. Volume, energy and cyclicity of eruptions of Arenal volcano, Costa Rica. Bull. Volcanol. 37, 416-437.

Melson, W.G., Barquero, J., Sáenz, R., Fernández, E., 1986. Erupciones explosivas de importancia en volcanes de Costa Rica. Bol. Vulcanol., vol. 16. Univ. Nacional, Costa Rica, pp. 15-20.

Mueller, M., 1984. Appendix A: the Silencio stratigraphic sequence. Vínculos 10 (1-2), 51-55.

Newhall, C.G., Self, S., 1982. The volcanic explosivity index (VEI): an estimate of explosive magnitude for historical volcanism. J. Geophys. Res. 87 (C2), 1231-1238.

Pyle, D.M., 1989. The thickness, volume and grainsize of tephra fall deposits. Bull. Volcanol. 51, 1-15.
Sachs, P.M., Alvarado, G.E., 1996. Mafic metaigneous lower crust beneath Arenal volcano (Costa Rica): evidence from xenoliths. Bol. Obs. Vulcanol. Arenal 6 (11-12), 71-78 (San José).

Sáenz, R., 1977. Erupción del volcán Arenal en el año 1968. Rev. Geogr. Am. Cent. 5-6, 149-188.

Sallares, V., Danobeitia, J.J., Flueh, E.R., Leandro, G., 1999. Seismic velocity structure across the Middle American landbridge in northern Costa Rica. Geodynamics 27, 327-344.

Sheets, P.D., 1984. The Proyecto Prehistórico Arenal: an introduction. Vínculos 10 (1-2), 17-29.

Sheets, P., Hoopes, J., Melson, W., McKee, B., Sever, T., Mueller, M., Chenault, M., Bradley, J., 1991. Prehistory and volcanism in the Arenal Area, Costa Rica. J. Field Archaeol. 18, 445-465.

Snarkis, M.J., 1984. Central America: the lower Caribbean. In: Lange, F.W., Stone, D.L. (Eds.), The archaeology of Lower Central America. Univ. New Mexico Press.

Soto, G.J., Arias, J.F., 1998. Síntesis de la actividad del volcán Arenal, año 1996. Bol. Obs. Sismol. Vulcanol. Arenal Miravalles 9 (17-18), $11-18$.

Soto, G.J., Alvarado, G.E., Madrigal, L.A., 1996. Las posibles erupciones del volcán Arenal en 1915 y 1922. Bol. Obs. Vulcanol. Arenal 6 (11-12), 45-52, 1993, San José.

Soto, G.J., Alvarado, G.E., Ghigliotti, M., 1998. El registro eruptivo del Arenal en el lapso 3000-7000 años antes del presente y nuevas deducciones sobre la edad del volcán. Bol. Obs. Sismol. Vulcanol. Arenal Miravalles 9 (17-18), 19-49 (San José).

Soto, G.J., Alvarado, G.E., Bonilla, J., Madrigal, J., Mata, A., Ramírez, R., Rojas, L., Salazar, J., Tristán, E., Villegas, A., 2000. Las facies proximales de la gran erupción piroclástica basáltica ET3 del volcán Arenal. Bol. Obs. Sismol. Vulcanol. Arenal Miravalles 12 (23-24), 54-63 (San José).

Street-Perrot, F.A., Perrot, R.A., 1990. Abrupt climate fluctuations in the tropics: the influence of Atlantic Ocean circulation. Nature 343, $607-612$.

Stuiver, M., Reimer, P.J., Bard, E., Beck, J.W., Burr, G.S., Hughen, K.A., Kromer, B., McCormac, F.G.v.d., Plicht, J., Spurk, M., 1998. ${ }^{14} \mathrm{C}$ calibration datasets. Radiocarbon 40, 1041-1083.

Tournon, J., Alvarado, G. (1995). Carte géologique - Mapa geológico de Costa Rica. Scale 1: 500 000. Imprimerie La Vigie, Dieppe, France.

Wadge, G., 1984. The magma budget of Volcán Arenal, Costa Rica, from 1968 to 1980. J. Volcanol. Geotherm. Res. 19, 281-302.

Wadge, G., Oramas Dorta, D., Cole, P.D., this volume. The magma budget of Volcán Arenal, Costa Rica, from 1980 to 2004. J. Volcanol. Geotherm. Res.

Walker, G.P.L., 1973. Explosive volcanic eruptions - a new classification scheme. Geol. Rundschau 62, 431-446.

Yao, Z.S., Quintero, R., Roberts, R.G., 1999. Tomographic imaging of $\mathrm{P}$ - and S-wave velocity structure beneath Costa Rica. J. Seismol. 3 , 177-190. 